\title{
The Concept of "Religion" in the Supreme Court of Israel
}

\author{
Aaron R. Petty* \\ [L]egal principles may have a strong relationship to a particular \\ religious heritage - a relationship which is so deep that we do not \\ always recognize it. ${ }^{\dagger}$
}

\section{INTRODUCTION}

Fifteen years ago, Joseph Dan reminded us that "there is no 'neutral' linguistic expression, one which does not reflect various layers of cultural and conceptual meanings." Legal discourse is no exception. "The cultural study of law shows that legal controversies and legal reasoning often reflect underlying cultural perceptions." ${ }^{2}$ And how law accounts for, responds to, and is imbued with cultural phenomena is far more important than "mere abstract intellectual exercises"3 that the lack of neutral expression may cause in other disciplines. In law, cultural conceptions and common understandings are "embedded in passionate social disputes on which the law of the state pronounces." imbued with common terms and concepts, and neutrality is assumed rather than demonstrated, "it is not ... a harmless affair."

\footnotetext{
* B.A., Northwestern University, 2004; J.D., University of Michigan Law School, 2007; M.St., University of Cambridge, 2012; Ph.D. candidate, University of Leiden. This article is dedicated to the memory of Julius $O$. Isler.

$\dagger$ Margaret Davies, Pluralism in Law and Religion, in LAW AND RELIGION IN THEORETICAL AND Historical CONTEXT 72, 80 (Peter Cane et al. eds., 2008).

1. Joseph Dan, Jewish Studies and European Terminology: Religion, Law and Ethics, in JEWISH STUdies in a New EuRope: Proceedings OF THE FIFTH CONGRESS OF JeWISH STUdies IN COPENHAGEN 1994 UNDER THE AUSPICES OF THE EUROPEAN ASSOCIATION FOR JEWISH STUDIES xxiii, xxiii (Ulf Haxen et al. eds., 1998).

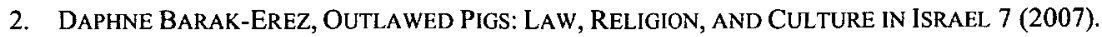

3. Talal Asad, Reading a Modern Classic: W. C. Smith's The Meaning and End of Religion, 40 HIST. RELIGIONS 205, 220 (2001).

4. Id.

5. Arie L. Molendijk, In Defence of Pragmatism, in The Pragmatics of Defining Religion: CONTEXTS, ConCEPTS AND ConTESTS 3, 6 (Jan G. Platvoet \& Arie L. Molendijk eds., 1999) (internal quotation omitted).
} 
In this Article, I suggest that "religion," both as it is commonly understood, and as it is understood and applied by courts as a legal term of art, refers chiefly to belief. This understanding of "religion" is incorrectly, if tacitly, assumed to be both neutral and broadly applicable. Building on previous work focusing on British courts, ${ }^{6}$ I now turn to investigating how Israeli courts understand the concept of religion. And, as before, I focus on cases addressing the question "who is a Jew?" as a window into how courts understand religion and membership in a religion more generally.

"Among the Western-style modern democracies there is no other country which experiences more intensely the problem of religion's place in the state than Israel."7 The country contains a "deeply divided society" 8 and, as a result, where the state and religion meet "even simple matters become complicated."

One such complication is Israel's status as both a Jewish and democratic state. "The Jewish-Israeli case - that of the Jewish people, the Jewish national movement-Zionism-and the Jewish nation-state-Israel-is . . . often said to be unique." 10 This is because "[b]eyond the ordinary tasks of a modern secular democratic state, Israel's specific mission is to constitute the national state of the Jews and to preserve and further Jewish national culture."11 Reconciling these dual and perhaps sometimes incompatible roles "is an issue with which Israeli courts have been struggling ever since the establishment of the state in 1948."12 And within that legal discourse "[n]o single problem ... has received as much attention as the definition of the word "Jew." "13

Israeli law uses the term "Jew" in relation to the jurisdiction of rabbinical courts, the law of return, and matters of personal registration. ${ }^{14}$ In particular, while "Jew" as a legislative term of art "has been accorded a religious definition in matters pertaining to the rabbinical courts, other

6. Aaron R. Petty, "Faith, However Defined": Reassessing JFS and the Judicial Conception of Religion, 6 ELON L. REV. 117 (2014).

7. Izhak Englard, Law and Religion in Israel, 35 AM. J. COMP. L. 185, 185 (1987).

8. Gila Stopler, Religious Establishment, Pluralism and Equality in Israel-Can the Circle be Squared?, 2 OXFORD J.L. \& REL. 150, 150 (2012).

9. Amnon Rubenstein, State and Religion in Israel, 2 J. CONTEMP. HIST. 107, 107 (1967).

10. Alexander Yakobson, Jewish People and the Jewish State, How Unique?-A Comparative Survey, 13 ISRAEL STUD. 1,1 (2008).

11. Englard, supra note 7, at 187.

12. Daniel B. Sinclair, Introduction, in JEWISH LAW ASSOCIATION STUDIES XI: LAW, JUdICIAL POLICY, AND JEWISH IDENTITY IN THE STATE OF ISRAEL 1, 1 (Daniel B. Sinclair ed., 2000).

13. Id; see also S. Zalman ABRAMOV, PERPETUAL DILEMMA: JEWISH RELIGION IN THE JeWISH STATE 270 (1976) ("Of the many controversies periodically agitating public opinion in Israel, none is more acute and more fraught with emotion than the legal, religious, and historical definition of a Jew. No other issue has engendered so much dissention and public debate as this one."); Amy-Jill Levine, Reflections on Reflections: Jesus, Judaism and Jewish-Christian Relations, 8 STUD. JEWISHCHRISTIAN REL. 1, 9 (2013) ("The question 'who is a Jew' was a problem in antiquity, and it remains a problem today.").

14. Menashe Shava, Comments on the Law of Return (Amendment No. 2), 5730-1970 (Who Is a Jew?), 3 Tel Aviv U. STUD. L. 140, 141 (1977). 
definitions have been applied to the same term in other contexts." 15

As Judaism is the dominant religion in Israel, how Israeli courts understand "who is a Jew" in a legal context says a great deal about how those courts understand religion more generally. This legal understanding reveals factors that the courts would likely find relevant in deciding what makes a religion a religion. Accordingly, I am not particularly concerned with the answer to the question "who is a Jew"-if there is one (or even if there are many). ${ }^{16}$ Instead, I am interested in how the question has been answered by courts of law and what the shape of the legal discourse has been in responding to that question; I am interested in what assumptions have been made, and in what factors have been determinative.

To set the legal issues in context, in Part II, I briefly trace the emergence of the State of Israel. Part II.A discusses the early Zionist movement with particular attention to the philosophy of Theodor Herzl. Part II.B traces the early legal foundations of the State of Israel from the Balfour Declaration through the Proclamation of the State. Part III concerns the legal system created by the State. Part III.A introduces the legal structure of the state of Israel. Part III.B details the function and authority of the courts within that structure. Part III.C addresses the legal status of religion in the state, and Part III.D looks at the Law of Return, a unique feature of Israeli law applicable only to Jews (and certain relations). Part IV concerns the substantive debate on "Who is a Jew" under Israeli civil law. Part IV.A discusses in detail three seminal cases addressing the legal relationship between Judaism and the State-Rufeisen (also known as Brother Daniel), Shalit, and Beresford-along with significant legislation passed in the wake of Shalit. Part IV.B attempts to reconcile these decisions and tease out the factors that the Israeli Supreme Court has considered significant and the assumptions that it has made in adjudicating issues of religious identity.

Part V turns to the historical validity and neutrality of the understanding of "religion" applied by the Israeli Supreme Court. Part V.A offers an overview of the Christian origins of the modern concept of "religion" as primarily a matter of belief. Part V.B reflects on how the Jewish state, through its secularist Supreme Court, could have come to a Christian understanding of religion. Finally, Part VI takes a step back to place the findings in the wider debate on secularization. Part VI.A provides the

15. Id.; see also ABRAMOV, supra note 13, at 270 ("[I]n Israel the problem has been focused... on the legal definition of who a Jew is.").

16. As Gad Barzilai has persuasively argued, the question of "Who is a Jew" is "not a static question or a fixed dilemma but rather a dynamic construction of political interests amid struggles of communities over political power. Thus the issue of 'who is a Jew' is not an autonomous problem waiting to be politically and legally resolved but rather a social language that serves the political purposes of social engineering." Gad Barzilai, Who is a Jew? Categories, Boundaries, Communities and Citizenship Law in Israel, in BOUNDARIES OF JEWISH IDENTITY 27, 28 (Susan Anita Glenn \& Naomi B. Sokoloff eds., 2010). 
necessary background on this secularization paradigm, and Part VI.B suggests that these cases may point to a useful refinement. Part VII offers a brief conclusion.

\section{THE EMERGENCE OF THE STATE OF ISRAEL}

The modern state of Israel claims an ancient pedigree. In 586 B.C. Babylonians captured the land of Israel and forced a significant portion of the population to relocate to Babylon. ${ }^{17}$ After the return from exile the Israelite population flourished for several centuries, but the conversion of Constantine to Christianity in the fourth century signaled a period of decline in both population and status of Jews. ${ }^{18}$ Over the ensuing centuries, "Jews became united... by a sense of unique isolation, periodically accentuated by outbursts of active anti-semitism." 19 And it was in this context of "shared persecution, made more bitter by frustrated attempts at assimilation, that Zionism grew." 20 The discussion of "Who is a Jew?" in the Supreme Court of Israel "takes place within the Zionist narrative of history."21

\section{A. The Zionist Movement}

"The Zionist movement arose in the context of nineteenth-century European nationalism and defined itself in opposition to the idea that Jews could be full members of a modern nation-state, whether French, German, or Russian, while adhering to their Jewish religion in their private lives."22 Instead, Zionism claimed that Jews constituted a nation themselves, ${ }^{23}$ and aimed to create a state for that nation. ${ }^{24}$ Over time, three main strands of Zionist thought emerged: religious, socialist, and "Zionism as refuge."25 What united all Zionists, however, was their agreement "on the need to

17. S.I. Strong, Law and Religion in Israel and Iran: How the Integration of Secular and Spiritual Laws Affects Human Rights and the Potential for Violence, 19 MICH. J. INT'L L. 109, 118 (1997).

18. Id. at 119.

19. Rubenstein, supra note 9, at 107.

20. Id. See also MENACHEM MAUTNER, LAW AND THE CULTURE OF ISRAEL 14 (2011) (noting that Zionism was a response to both "the distressing conditions of Jewish existence in Eastern and central Europe" and "an answer to the grave cultural crisis that Jews faced in the nineteenth century."). On the historical development of secular Judaism generally, of which Zionism is part, see ABRAMOV, supra note 13 , at $272-73$.

21. Daphne Barak-Erez, Collective Memory and Judicial Legitimacy: The Historical Narrative of the Israeli Supreme Court, 16 CANADIAN J.L. \& SOC'Y. 93, 109 (2001).

22. LEORA BATNITZKY, HOW JUdAISM BECAME a RELIGION: AN INTROdUCTION TO MOdERN JEWISH THOUGHT 147 (2011).

23. Id.

24. Zvi Gitelman, The Decline of the Jewish Nation: Boundaries, Content, and Jewish Identity, 4 JEWISH SOC. STUD., NEW SERIES 112, 112 (1998).

25. Lucy Endel Bassli, The Future of Combining Synagogue and State in Israel: What Have We Learned in the First Fifty Years?, 22 Hous. J. INT'L L. 477, 480 (2000). 
recreate a Jewish State-that is what made them Zionists." 26

Religious Zionists rejected the Orthodox Jewish religious tenet that the Jews will return to the land of Israel en masse only when the Messiah comes, and instead focused on the biblical promise of the land of Israel to the people of Israel. ${ }^{27}$ Socialist Zionism, by contrast, "rejected any association with traditional Judaism, including such basic tenets ... as observance of the Sabbath and dietary laws." 28 But "[t]he mainstream of Zionism," which ultimately led to the creation of the state, "tried to introduce an element of normalcy into an abnormal situation." 29 That is, it viewed Zionism as the preferable response to "the Jewish question" in Europe. $^{30}$

In the late nineteenth century, "[f]aced with the rise of anti-Semitism throughout Europe, Zionism, or Jewish nationalism, was revived by Theodor Herzl, an educated Western European Jewish journalist and author." "31 Herzl was born in 1860 in Budapest to an assimilated Jewish family. ${ }^{32}$ He studied law in Vienna and, as a young man, left an unpromising career as a playwright to take up journalism. ${ }^{33}$ In 1892 he became the Paris correspondent for Vienna's New Free Press, and in this capacity two years later he reported on the trial of Captain Alfred Dreyfus.

Following Germany's 1871 annexation of Alsace-Lorraine under the terms of the Treaty of Frankfurt, French support for Russia increased steadily. ${ }^{34}$ In this context, French Jews who were not favorably disposed toward Russia (as many were not, on account of anti-Jewish pogroms)

26. Martin Edelman, A Portion of Animosity: The Politics of Disestablishment of Religion in Israel, 5 ISRAEL STUD. 204, 205 (2000).

27. BATNITSKY, supra note 22, at 147.

28. BARAK-EREZ, supra note 2 , at 37.

29. Rubenstein, supra note 9, at 107. See also BATNITSKY, supra note 22, at 56 ("Zionism claims to seek the normalization of the Jewish people.").

30. Bassli, supra note 25 , at 481 . "The Jewish Question" broadly concerns the debate in Europe at the end of the nineteenth century concerning the appropriate treatment and status of Jews in society, with particular reference to political rights, and the extent to which Jewish identity (especially Jewish national identity) did or should prevent or limit integration and political participation in European states. The phrase appears to have entered broad usage following Bruno Bauer's 1843 work Die Judenfrage (The Jewish Question), and Karl Marx's 1844 response Zur Judenfrage (On the Jewish Question). The phrase, however, appeared much earlier in both English and French (la question juive), and at least the idea of Jewish emancipation had entered discussion in Germany close to a century earlier. See Gad Freudenthal, Aaron Salomon Gumpertz, Gotthold Ephraim Lessing, and the First Call for an Improvement of the Civil Rights of Jews in Germany (1753), 29 AJS REV. 299 (2005). Even ancient origins have been suggested. AVI AVIDOV, NOT RECKONED AMONG NATIONS: THE ORIGINS OF THE SO-CALLED “JEWISH QUESTION” IN ROMAN ANTIQUITY (2009).

31. Id. at 479. Although Herzl's contribution was undoubtedly more significant to the creation of the State of Israel, he was not the first to call for the establishment of a state. In 1882 Leo Pinsker published a pamphlet entitled Auto-Emancipation, which advocated for the creation of a Jewish state. See ABRAMOV, supra note 13, at 44.

32. ABRAMOV, supra note 13, at 60; BATNTSKY, supra note 22, at 152.

33. Id.

34. BATNITSKY, supra note 22 , at 152 . 
were seen as pro-German and, therefore, anti-French. ${ }^{35}$ Coupled with a simultaneous rise in French nationalism, the perceived anti-French attitude of French Jews heightened an atmosphere of antisemitism that culminated in the trial of Dreyfus. ${ }^{36}$

Dreyfus, like Herzl, was an assimilated Jew ${ }^{37}$ He hailed from Alsace (a German-speaking region) and was a career officer in the French Army. ${ }^{38}$ Accused of treason for allegedly communicating French military secrets to the German embassy in Paris, Dreyfus was subjected to a trial closed to both the public and journalists. ${ }^{39}$ Despite his claims of innocence and the lack of any reliable evidence against him, Dreyfus was convicted and sentenced to life imprisonment. ${ }^{40}$ After the verdict was announced, "mobs crowded the streets of Paris for days, shouting 'Death to the Jews." "41

The turning point in Herzl's life was his coverage, as a journalist, of the Dreyfus affair and "its attendant outbursts of antisemitism." ${ }^{42} \mathrm{He}$ later claimed, "The Dreyfus trial... which I witnessed in Paris in 1894, made me a Zionist. ${ }^{43}$ He claimed that this injustice, and the public sentiment that followed, demonstrated the ultimate futility of Jewish assimilation in Europe. If the most enlightened of European countries - in his words, "republican, modern, civilized France one hundred years after the declaration of the Rights of Man"-could not tolerate even the most assimilated of Jews - a Jewish officer in the French Army - there could be

35. Id.

36. Id.

37. Id.

38. Id.

39. Id.

40. Id. Dreyfus spent almost five years as a prisoner on Devil's Island in French Guiana. In 1896, Colonel Georges Picquart, the head of counterespionage in the French Army, identified Major Ferdinand Walsin Esterhazy as the real spy. For this discovery, Picquart was transferred to Tunis. Esterhazy was tried, but acquitted, and some historians theorize that Esterhazy was, in fact, a double agent. After Esterhazy's acquittal, both Dreyfus and Picquart faced charges related to the documents implicating Esterhazy.

In January 1898, Émile Zola published J'accuse, an open letter claiming that Dreyfus was framed. Leading intellectuals began to call for the case to be reopened. Dreyfus was returned to France in 1899 , re-tried, and again convicted. He was sentenced to ten years' imprisonment but pardoned and set free shortly after the trial. It was not until 1906 that Dreyfus was fully exonerated. He was reinstated as a Major in the French Army, served during World War I, and retired as a Lieutenant Colonel. Picquart, who had left the Army, was reinstated and promoted to Brigadier General and later served in the Clemenceau cabinet as Minister of War.

There is a wealth of literature on the Dreyfus affair. For the broad outlines, see, for example, Louls Begley, Why the DReyfus AfFair MatTERs (2009); MichaEl BuRnS, FranCE AND THE Dreyfus AfFair: A Brief DOCUMENTARY History (1999); PIERS PAUl READ, THE Dreyfus AFFaIR (2012).

41. BATNITSKY, supra note 22 , at 152.

42. Rubenstein, supra note 9 , at 108.

43. BATNITSKY, supra note 22, at 152 (quoting THEODOR HERZL, ZIONIST WRITINGS: ESSAYS AND ADDRESSES 2:112 (Harry Zohn trans., 1973). Batnitzky notes that some recent scholarship has cast doubt on Herzl's claim about the centrality of the Dreyfus affair to the development of his own Zionist thought, and that the importance Herzl later ascribed to the Dreyfus affair may be a "belated contrivance," Id. 
no hope for assimilation of any Jews anywhere in Europe. ${ }^{44}$ An alternative was required. In the aftermath of the Dreyfus affair, Herzl wrote his seminal essay, Der Judenstaat, in which he proposed "the Jews 'be granted sovereignty over a portion of the globe large enough to satisfy the rightful requirements of a nation." "45 This 1896 publication "brought the concept of creating a Jewish homeland to the attention of international leaders and politicians. ${ }^{\prime 46}$

Herzl prioritized the physical survival and political emancipation of individuals over the survival of Jewish religion or culture. ${ }^{47}$ Indeed, in Der Judenstaat, Herzl "depicted the future state in terms of the European atmosphere which he knew among the liberal assimilated Jews of Central Europe." ${ }^{48}$ Even the title of his work, although often translated into English as "The Jewish State" means something closer to "the Jews' state." ${ }^{49}$ In other words, for Herzl, "the state is for the sake of the survival of Jews, and not for the sake of the survival of Judaism or some form of Jewishness." ${ }^{50}$ And as in other European states, religion, as he understood it, was to be subordinated to the state:

Are we eventually going to set up a theocracy? No! Belief holds us together, science makes us free. We are not going to allow our rabbis even to think about theocratic ideas. We are going to know how to restrict them to their synagogues just as we are going to retain our army within their bases. Army and rabbinate shall be honoured deeply as is becoming to their high function and merits. They have no word to say in the affairs of the State which has thus honoured them because they would bring about internal and external complications. ${ }^{51}$

This subordination of religious authority to the state was "the very foundation" of the secular Zionist movement. ${ }^{52}$ But if Judaism could acquire a secular meaning, then who was a Jew? And could, for instance, a Jew who converted to another religion still be a Jew and a member of the Zionist movement? ${ }^{53}$ The following year, Herzl participated in convening the World Zionist Congress, held in Basel on August 29, 1897. The

44. Cf. MAUTNER, supra note 20 , at 14 (noting that Zionism was precipitated by "the rejection of the Jews' attempt to be accepted as equals by the non-Jewish societies in which they lived.").

45. ABRAMOV, supra note 13 , at 60 ; see also Bassli, supra note 25 , at $479 \mathrm{n} .9$.

46. Bassli, supra note 25 , at 480 .

47. BATNITSKY, supra note 22 , at 154 .

48. Rubenstein, supra note 9, at 108.

49. BATNITSKY, supra note 22, at 154; ABRAMOV, supra note 13, at 60 ("This was nationalism pure and simple, in itself devoid of any religious content.").

50. Id; see also ABRAMOV, supra note 13, at 60 .

51. Rubenstein, supra note 9, at 108.

52. Id. See also Englard, supra note 7, at 187 ("The mainstream of modern political Zionism, which led to the establishment of the State of Israel in 1948, was . . guided by this idea of a national secular Jewish state.").

53. Rubenstein, supra note 9, at 108. Herzl's response to the latter question was "no." Id. at 109. 
Congress, in turn, created a permanent Zionist Organization (now known as the World Zionist Organization) through which it could work to implement its policy decisions. ${ }^{54}$

\section{B. Early Legal Foundations}

\section{The Balfour Declaration}

The work of the Zionist Organization eventually resulted in the support of the British government. On November 2, 1917, British Foreign Secretary Arthur Balfour, in a letter to Lord Rothschild, President of the British Zionist Federation, called for the establishment of a national Jewish homeland. ${ }^{55}$ Balfour's letter, which later became known as the Balfour Declaration, was preceded by significant pressure from Zionist groups, ${ }^{56}$ but was also intended to raise Jewish support and capital for the British war effort, to ensure British control over strategically-important Palestine if the Ottoman Empire collapsed in the wake of the war, ${ }^{57}$ and to garner support from both the United States and the Soviet Union. ${ }^{58}$ Although the Declaration was in some ways cautious, preferring the term "national home" to "Jewish state" and avoiding mention of specific geographical boundaries, it was nevertheless a significant victory for the Zionist movement. ${ }^{59}$

\section{The League of Nations Mandate}

As the British government had anticipated, the Ottoman Empire did collapse after the war, and in 1922 the nascent League of Nations granted the United Kingdom a Mandate for Palestine, legitimizing British rule in the Levant. ${ }^{60}$ The text of the Mandate incorporated the Balfour Declaration. $^{61}$ The Mandate continued the policy set out in the Declaration, but stopped short of preparing the way for an independent Jewish state. ${ }^{62}$ Jewish immigration to Israel during the Mandate period,

54. Bassli, supra note 25 , at 480 .

55. Id. The Declaration noted that "His Majesty's Government view with favour the establishment in Palestine of a national home for the jewish people, and will use their best endeavours to facilitate the achievement of this object. ..." ABRAMOV, supra note 13, at 85.

56. Nancy Caren Richmond, Israel's Law of Return: Analysis of Its Evolution and Present Application, 12 DICK. J. INT'L L. 95, 96 n.7 (1993); ABRAMOV, supra note 13, at 84 (noting the Declaration was the result of "[a] series of well-coordinated diplomatic moves on the part of Zionist leaders in London, Paris, Rome, and Washington").

57. Bassli, supra note 25 , at 483.

58. JAMES GELVIN, THE ISRAEL-PALESTINE CONFLICT: 100 YEARS OF WAR 82-83 (2005).

59. Bassli, supra note 25 , at 482 .

60. Id. at 483. The Mandate was assigned to the United Kingdom in 1920, the terms were approved by the League of Nations in 1922, and it came into effect in 1923.

61. Richmond, supra note 56 , at $96 \mathrm{n.8}$.

62. Bassli, supra note 25 , at 483 . 
until 1937, was based on the ability of the territory to economically absorb Jewish immigrants without significantly shifting the social make-up of the territory between Jews and Arabs. ${ }^{63}$

\section{The MacDonald White Paper}

At the same time that the British government had been negotiating with Zionists regarding the establishment of a Jewish homeland, it had also promised to Arab leaders an independent Arab state in the same territory in exchange for support against the Ottomans. By the late 1930s, though, Hitler's Nuremburg Laws had triggered mass Jewish exodus from Germany and the influx of Jewish refugees had spawned Arab revolts in Mandatory Palestine. By 1939, the British government believed that Jewish support was either guaranteed or unnecessary, while losing the support of the Arab world would be disastrous. ${ }^{64}$

Thus, that year Colonial Secretary Malcolm MacDonald issued a White Paper declaring that the resettlement of 450,000 Jews had fulfilled the Balfour Declaration's promise of a homeland for the Jewish people, and called for the creation of a state to be governed by Jews and Arabs jointly, providing that it should not be a "Jewish State," that further Jewish immigration would be restricted, and that the transfer of land from Arabs to Jews also be restricted ${ }^{65}$ Lloyd George called the White Paper an act of perfidy and Winston Churchill voted against the Paper and the government in which he was a minister. Even the League of Nations' own Permanent Mandates Commission abstained from endorsing the White Paper, and several of its members thought MacDonald's views inconsistent with the Mandate ${ }^{66}$ The British government's new policy led to significant illegal immigration by European Jews and eventually a naval blockade. The significance of the situation was highlighted by James Rothschild MP, who said, "[f]or the majority of Jews who go to Palestine it is a question of migration or of physical extinction." Second World War.

For many, "Zionism alone emerged as a viable Jewish response" to the Holocaust. ${ }^{68}$ The near-total annihilation of European Jewry seemed to confirm Herzl's doubts about the possibility of assimilation. ${ }^{69}$ It also

63. RUTH GAVISON, THE LAW OF RETURN AT SIXTY YEARS: HISTORY, IDEOLOGY, JUSTIFICATION $21(2010)$.

64. RAUl HiLBERG, THE DESTRUCTION OF THE EUROPEAN JEWS 716 (1961).

65. Bassli, supra note 25, at 483. See also GAvISON, supra note 63, at 21 (noting that the British government established stricter limits on Jewish immigration to Mandatory Palestine after the 1936-39 Arab uprisings).

66. HILBERG, supra note 64 , at $717 \mathrm{n} .7$.

67. 347 PARL. DEB., H.C. (5th Ser.) (1939) 1984 (U.K.).

68. Richmond, supra note 56 , at 95 (internal quotation omitted).

69. BATNITZKY, supra note 22, at 94 ("For Fackenheim, the Holocaust discredits the false promises of secular modernity, including the notion that Jews can be integrated as full citizens in a 
"demand[ed] that secular and religious Jews unite in resisting any future threat to the existence of the Jewish people." "70 Zionism promised safety and security for Jews that the countries of Europe had failed to provide. As the Jewish Agency put it:

When we say "Jewish independence" of a "Jewish state" we mean Jewish country, Jewish soil; we mean Jewish labour, we mean Jewish economy, Jewish agriculture, Jewish industry, Jewish sea. We mean Jewish language, schools, culture. We mean Jewish safety, security, independence, complete independence, as for any other free people. ${ }^{11}$

\section{The Proclamation of the State of Israel}

On November 27, 1947, the General Assembly of the United Nations adopted a resolution calling for the establishment of an independent Jewish state in Palestine, but the British Mandate remained in place until midnight on May 15, 1948." "The establishment of Israel was the successful culmination of the Zionist movement" that Herzl had revived just fifty years earlier. ${ }^{73}$ And "when David Ben-Gurion read the Israeli Proclamation of Independence in Tel-Aviv" the preceding afternoon, "everyone understood that the Zionists were establishing the first Jewish State in Palestine in two thousand years, but no one-not even the founders themselves - could indicate with certainty what was meant by the words 'Jewish State."'74 The Proclamation did provide, however, that "Israel will be open for Jewish immigration and the Ingathering of the Exiles." 75 And, almost immediately, aliyah from numerous overseas communities began. ${ }^{76}$ "In the state's first years ... tens of thousands made Aliyah from every corner of the world." 77

For many Israelis, the Proclamation "appears to embrace the Herzlian vision of a secular democratic state, thus representing the fulfillment of the Zionist dream. But the one lesson to be gleaned from any comprehensive history of the Jewish people is that there are several competing Zionist

modern nation-state.").

70. Id.

71. Bassli, supra note 25, at 485 (quoting THE JeWISH AGENCY FOR PALESTINE, THE JewiSH CASE 66 (1947)).

72. Richmond, supra note 56 , at 95 n.3; Strong, supra note 17 , at $119-20$ \& n.54; G.A. Res. 181 (II) at 131 , U.N. Doc. A/519 (Nov. 29, 1947)

73. Edelman, supra note 26, at 204-05.

74. Id. at 205 .

75. Proclamation of the State of Israel, 5708-1948, 1 LSI 3 (1948).

76. GAvison, supra note 63 , at 11.

77. Id. For example, "nearly the entire Jewish community of Bulgaria moved to Israel, as did the old established communities of Yemen, Iraq, and Libya, and the vast majority of those who had survived in Poland, Hungary, Czechoslovakia, and Rumania. Tens of thousands came from Morocco, Tunis, Turkey, Persia, and India." ABRAMOV, supra note 13, at 147. 
visions: the Zionist dream does not exist." 78 The most that can be said is that the Proclamation embodies a commitment to individual rights, as well as a vision of the Jewish people collectively as a nation. ${ }^{79}$ "[T] he rights of individuals are in important and perhaps contradictory ways bound up with the organic nature of the community and its constituent parts." tension inherent in Israel's dual status as a "Jewish and democratic" state, concerned with both individuals and the Jewish people as a whole, has never been resolved. ${ }^{81}$

\section{THE ISRAELI LEGÄL SYSTEM}

One place this tension manifests is in the preferential treatment accorded to Jewish immigrants under the Law of Return. "The Law of Return serves as a focus for controversy, both with respect to the justification for the preference given to Jews in Israeli immigration policy, ${ }^{82}$ and with respect to the internal Jewish question regarding the essence of the Jewish collective and the standards for identifying its members or becoming one. $" 83$

\section{A. The Constitutional Structure}

Any discussion of Israeli law must begin with the most distinctive feature of its legal system: the lack of a formal constitution. ${ }^{84}$ Although the Proclamation promised a constitution, the Knesset was never able to pass one. Instead, a number of Basic Laws have been passed, which have a quasi-constitutional status. ${ }^{85}$ For many years, it was thought that Basic Laws were not inherently superior to ordinary legislation because absent an "entrenchment provision" requiring some specified supermajority to modify or repeal a Basic Law, they could be modified or repealed at the pleasure of the Knesset. ${ }^{86}$ But at the same time, Basic Laws were thought

78. GARY JEFFREY JACOBSON, APPLE OF GOLD: CONSTITUTIONALISM IN ISRAEL AND THE UNITED STATES 7 (1993).

79. Cynthia A.M. Stroman, Book Review, 91 MICH. L. REV. 1545, 1546 (1993).

80. JACOBSON, supra note 78 , at 8 .

81. Edelman, supra note 26, at 218 ("Israel has never resolved the relationship between Judaism (the religion of the Jews) and Jewish national identity."); Barzilai, supra note 16, at 29 ("Zionism, as an aggregate of various Jewish national aspirations, has not clearly differentiated Jewish ethnicity from religious or from nationality. Consequently, public contentions over the issue 'who is a Jew' have been paramount for allocations of citizenship rights in Israel since the formal inception of the state in 1948."); JACOBSON, supra note 78, at 8 ("the achievement of liberal goals pertaining to individual rights will have to accommodate communitarian goals with which they will often be in conflict.").

82. See, e.g., Stopler, supra note 8; GAVISON, supra note 63, at 37-59.

83. GAVISON, supra note 63, at 11 .

84. Englard, supra note 7, at 190; Strong, supra note 17, at 135.

85. Strong, supra note 17 , at 135 . The Proclamation is also legally binding, but only to the extent that it "expresses the vision of the people and its faith." Id. at 136.

86. Id. at 135 . 
"fundamental in some ill-defined sense."

\section{B. The Role of the Courts}

Although the Israeli Supreme Court has been functioning since shortly after the foundation of the state, its role was codified in a Basic Law only in 1984. The Israeli Supreme Court serves two functions. It is an appellate court of last resort, and also a court of first instance for claims against the state in matters not under the jurisdiction of any other tribunal. ${ }^{88}$ "Any person who has reason to believe that a particular state action denies her legal rights may petition the court and ask it to issue an order nisi," which the court will "consider rapidly and inexpensively." ${ }^{89}$ A single judge reviews the petition, and may direct the respondent to show cause why the relief requested should not be granted. ${ }^{90}$ After a hearing, the court may grant permanent injunctive relief. ${ }^{91}$

For many years, the absence of a written constitution led the Supreme Court to "develop a position of judicial restraint[,] ... preferring to leave many fundamental questions to the legislature." ${ }^{\circ 2}$ And despite its initially limited authority to review legislation passed by the Knesset, the Supreme Court was able to "ensure that public officials and agents of the state [did] not abuse their powers of discretion" $" 93$ because "a high percentage of laws in Israel consists not of primary legislation but of secondary legislation passed by administrative bodies to implement primary enactments." ${ }^{.94}$ (In 1995 the Supreme Court "took the revolutionary step of declaring that Israel no longer lacked a written constitution" and that "[h]enceforth ... the Eleven Basic Laws that had been periodically enacted by the Knesset would function as the nation's constitution," 95 but this development postdates the decisions under consideration here.)

\section{The Legal Status of Religion}

Israel is not a theocracy, nor is there even any established religion. ${ }^{96}$

87. Id. at 113 n. 10 (quoting Martin Edelman, Courts, Politics, And Culture IN ISRael 30 (1994)).

88. Ronen Shamir, "Landmark Cases" and the Reproduction of Legitimacy: The Case of Israel's High Court of Justice, 24 LAW \& SOC'Y REV. 781, 784 (1990); Strong, supra note 17, at 137.

89. Shamir, supra note 88 , at 784 .

90. Id.

91. Id.

92. Stroman, supra note 79 , at 1548 .

93. Shamir, supra note 88 , at 784 .

94. Strong, supra note 17 , at 138.

95. Edelman, supra note 26, at 209 (citing CA 6821/93 United Bank Mizrahi v. Migdal Coop. Vill. 49(4) PD221 [1995]. Having declared the existence of a constitution, the Supreme Court took it upon itself to review Knesset legislation for conformity with the constitution, arrogating to itself an American style of judicial review.

96. Edelman, supra note 26, at 206; Natan Lemer, Religious Liberty in the State of Israel, 21 EMORY INT'L L. REV. 239, 246 (2007). Alternatively, it has been suggested that "Israel does not have 


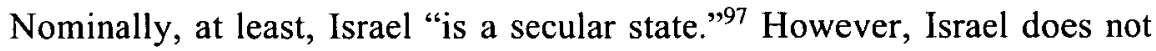
maintain the separation between religion and the state that characterizes, for example, the French and American legal regimes. ${ }^{98}$ Much of "Israeli law rests on the foundations of the legal system instituted during the British rule in Palestine between 1917 and 1948," a vestige of Ottoman rule-the millet system-under which " $[t]$ he courts of each [religious] community have exclusive jurisdiction over specific matters of personal status, particularly marriage and divorce." 100 This remnant of religious authority in personal matters means that the state "does more than simply recognize the existence of certain religions."

Indeed, the government "maintains formal links with the institutional organs of 14 religious denominations, and legally subjects individuals to religious rules by vesting the religious courts of those religions with the authority to resolve certain matters." 102 And because the vast majority of residents of Israel are Jewish, "Orthodox Judaism has functioned in the Israeli polity as if it were the official state religion," notwithstanding the modern, Western, secular outlook that dominated Israeli culture in the early twentieth century. ${ }^{103}$

Given this delegation and decentralization, "[t]he provisions of law relating to religion in Israel are not governed by any general scheme. History, political expediency, party politics and, even more, chance are responsible for an amorphous body of laws which baffles outsiders as well as some Israelis." 104 The state itself has even referred to its own relationship with religious bodies as "labyrinthine" and conceded that it consists of "a patchwork of laws and practices that are not easily susceptible to generalization." ${ }^{105}$ One area in which this confusion is manifest is the Law of Return, which permits Jews and certain non-Jewish relatives of Jews to immigrate to Israel and obtain Israeli citizenship.

an established religion; it has a multiple establishment." Edelman, supra note 26, at 206.

97. Lerner, supra note 96, at 244 (quoting HAIM COHEN, HUMAN RIGHTS IN JEWISH LAW 17 (1984)); BARAK-EREZ, supra note 2, at 4 ("In principle, Israeli law is a secular system with few exceptions.").

98. BARAK-EREZ, supra note 2, at 23.

99. Id. at 246 .

100. Edelman, supra note 26, at 206. See also BARAK-EREZ, supra note 2, at 4 ("In matters of marriage and divorce [Israeli law] makes the law of the various religious communities binding on their individual members, thereby preserving the approach of the British Mandate's legislation."). Article 9 of the Mandate for Palestine "scrupulously preserved ... the personal law and the system of religious community courts" by providing that "respect for personal status of the various peoples and communities and for their religious interests shall be guaranteed." ABRAMOV, supra note 13, at 93, 175.

101. Edelman, supra note 26, at 206.

102. Id. This model of interaction between the state and religion has been characterized as "stateorganized pluralism." See Paul Cliteur, State and Religion Against the Backdrop of Religious Radicalism, 10 INT'L J. CONST. L. 127, 132 (2012).

103. Edelman, supra note 26, at 206.

104. Amnon Rubenstein, Law and Religion in Israel, 2 ISRAEL L. REV. 380, 380 (1967).

105. Lerner, supra note 96 , at 239 (internal quotation omitted). 


\section{The Law of Return}

"Jewish aliyah and kibbutz galuyot ('the ingathering of the exiles') are two of the primary goals of the Zionist enterprise and of the State of Israel." 106 Like the Zionist project itself, "[a]liyah and the struggle for aliyah began years before the foundation of the state." 107 Indeed, "[d]eliberations on the subject of Aliyah have accompanied the Zionist enterprise from the beginning." 108

But it was not until two years after the Proclamation that Ben-Gurion fulfilled its promise that "Israel will be open for Jewish immigration." 109 Speaking before the Knesset on July 3, 1950, Ben-Gurion affirmed that Israel is a "state for all Jews wherever they may be" and emphasized that Israel's "gates are open to every Jew." 110 He explained that the Law of Return, which was then being debated, embodies the raison d'être of the state. "I Two days after Ben-Gurion's address, on Herzl's memorial day, the Knesset enacted the Law of Return by unanimous vote. ${ }^{112}$

As Ben-Gurion explained in his address to the Knesset, the Law of Return "is regarded as one of the pillars of the (unwritten) Israel constitution, in the sense that it gives effect to one of the basic purposes of the very establishment of the state." 113 That is, it "was enacted in order to secure a safe place for all Jews in their own homeland after the Holocaust." 114 But more than simply providing refuge for Jews, wherever they may be, "[t]he Law of Return is one of the main legal instruments designed to make Israel the state of the Jews." 115 In this respect, the Law

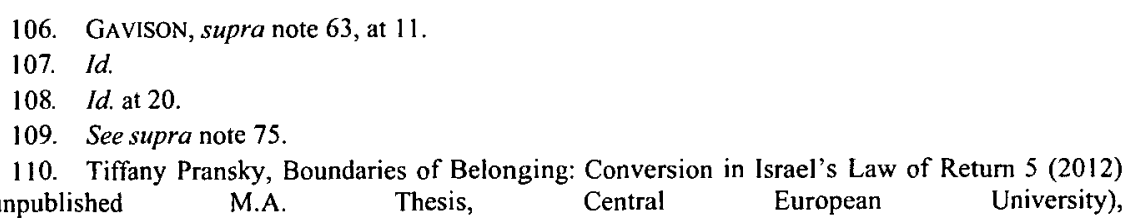
$\begin{array}{llll}\text { (unpublished M.A. Thesis, Central } & \text { Turop } \\ \text { http://www.etd.ceu.hu/2012/pransky_tiffany.pdf. Last accessed May 1, } 2014 .\end{array}$

111. Id. See also GUY BEN-PORAT \& BRYAN S. TURner, THE CONTRAdictions of ISRAElI Citizenship 11 (2011).

112. Pransky, supra note 110, at 5; GAVISON, supra note 63, at 24.

113. Bernard S. Jackson, Brother Daniel: The Construction of Jewish Identity in the Israel Supreme Court, 6 INT'L J. FOR SEMIOTICS LAW 115, 123-24 (1993).

114. BARAK-EREZ, supra note 2, at 83; see also GAVISON, supra note 63, at 17 "The 1950 Law of Retum was the political, symbolic and legal instrument with which the state fulfilled its obligation.").

115. Nahshon Perez, Israel's Law of Return: A Qualified Justification, 31 MODERN JUDAISM 59, 60 (2011). See also id. ("The Law of Return aims to enable the immigration of all Jews to Israel, regardless of . . . any other characteristic."); Claude Klein, The Right of Return in Israeli Law, 13 TEL. AVIV U. STUD. Law 53, 56 (1997) ("The State of Israel is the state of the Jewish people, and, therefore, its gates are completely open to Jewish immigration."); Shalev Ginossar, Who is a Jew: $A$ Better Law?, 5 ISRAEL L. REV. 264, 265 (1970) ("As everyone knows, the main concern of the State of Israel is to keep its gates wide open for every prospective oleh, i.e. for every Jew retuming to settle in the land of his forefathers."); Yfaat Weiss, The Golem and Its Creator, or How the Jewish NationState Became Multiethnic, in Challenging ETHNiC Citizenship: German and ISRAEl PERSPECTIVES 82, 82 (Daniel Levy \& Y faat Weiss eds., 2002) (noting the Law of Return and the Citizenship Law are "a fundamental expression of the fact that Israel was created as the Jewish state"); 
of Return enabled the State to provide an answer to the "Jewish question," not just in Europe (to the extent that the Holocaust had not already rendered it moot) but everywhere. Accordingly, The Law of Return "is perceived by many as one of the major expressions of the state's Jewishness." 116

"Section 1 of the Law of Return provides that every Jew has the right to immigration to Israel."117 "In practice, in order to realize his or her right of return, an entitled individual must obtain a special visa known as an oleh's visa." 118 Under Sec. 2(b), an oleh's visa "shall be granted" to every Jew who has expressed his desire to settle in Israel (provided the applicant does not fall within one of three little-used exceptions on which a visa may be denied for reasons of public health or security). ${ }^{119}$ Thus,

[i]n principle, where an applicant is a Jew and where he or she does not fit into one of the three categories enumerated in section 2(b), the Minister of the Interior has no discretionary power. An oleh's visa must be granted to the individual, since the right of return is an inherent right for every Jew. ${ }^{120}$

The Law of Return itself does not deal with the granting of citizenship, but rather only with aliyah." 21 But the Citizenship Law provides that "[e]very oleh by virtue of the 1950 Law of Return will be a Israeli citizen." 122 This has been interpreted to mean automatically and immediately. ${ }^{123}$ Other avenues to citizenship exist, and include citizenship by residence (the primary path to Israeli citizenship for Arabs who had been citizens of Mandatory Palestine), birth, and naturalization (other than under the Law of Return). ${ }^{124}$ But the essentially unlimited right of every Jew to immigrate to Israel and the availability of immediate and automatic Israeli citizenship for every oleh means that "for purposes of the Law of

Barzilai, supra note 16, at 29 (noting the Law of Return and Citizenship Law "were more important in Israel than any other piece of legislation, including the Basic Laws, since they were supposed to entrench Jewishness as the main political force in state ideology, legal ideology, and public policy").

116. GAVISON, supra note 63, at 11. But see Sinclair, supra note 12, at 2 ("[T]he actual legal issues involved, i.e. automatic citizenship and registration, are not of any great practical significance. In this respect, this area is a relatively 'safe' one for the conduct of high-level legal debate as to the State of Israel's Jewish character.").

117. Shava, supra note 14 , at 141.

118. Klein, supra note 115, at 56. This was perhaps not always so. Slovenko suggests that, at one point, a Jew could immigrate "without passport or number." Ralph Slovenko, Brother Daniel and Jewish Identity, 9 ST. LouIS U. L.J. 1, 3 (1964).

119. Klein, supra note 115 , at 56.

120. Id. at 57 (emphasis added).

121. GAVISON, supra note 63 , at 30 .

122. Id.

123. Id. See also Perez, supra note 115, at 60 ("Immigrants entering Israel under the Law of Return are eligible immediately for full citizenship.").

124. GAVISON, supra note 63 , at 30-31. Both Jews and non-Jews may be naturalized outside of the process used for the Law of Return, but it does require a longer period of residence and a favorable exercise of discretion by the Minister of the Interior. Id. at 31; Slovenko, supra note 118, at 3-4. 
Return the answer to the question 'Who is a Jew?' is of great importance." 125

"In the period before the founding of the State and in the first years following it, the authorities did not define the term 'Jewish' but rather made do with a declaration from the aliyah applicant that he or she was Jewish." 126 The assumption was that few people would identify as Jews, much less immigrate to a besieged and struggling state, if they were not actually Jewish. ${ }^{127}$ As Ruth Gavison writes, "[w]hen the Law of Return was formulated, shortly after the fall of Hitler, it was hardly thought, especially by those who shared Heinrich Heine's belief that 'Judaism is not a religion but a misfortune,' that there would be people claiming to be Jews." ${ }^{28}$ Ben-Gurion himself explained:

I was in the Jewish Agency for fifteen years and I do not recall that anyone raised this question. I was in the Jewish Agency for thirteen years together with Rabbi Maimon and Mr. Moshe Shapira. When a Jew arrived, I never once heard either of them asking who his mother and father were. Nobody asked this. If a Jew came and said he was a Jew-that was sufficient. ${ }^{129}$

During the discussions on the draft bill, the Knesset rejected the proposal of the religious Agudat Israel party to define "Jew" halakhically - one whose mother is Jewish or who converts to Judaismand Ben-Gurion expressed opposition to such a definition several times. ${ }^{130}$ Ultimately, the Knesset did not define "Jew." Some have suggested that

125. Shava, supra note 14, at 141. See also GAVISON, supra note 63 , at 61 ("Accordingly, the questions, 'Who is a Jew' and 'Who is a member of the Jewish people' are of decisive importance."). The number of Jews that have immigrated to Israel under the Law of Return is substantial. Perez, supra note 115, at 61. Approximately 1.4 million immigrated between 1948 and the mid-1950s (mostly Holocaust survivors and those living in Muslim states), and almost one million from the former U.S.S.R. in the 1990s. Id. "It is unlikely that another massive wave of immigrants will arrive in Israel, short of an unforeseen event." $I d$. In recent years, immigration under the Law of Return has been modest: between 10,000 and 15,000 immigrants annually. Id.

126. GAVISON, supra note 63 , at 62 .

127. $I d$.

128. Slovenko, supra note 118 , at 4 . Or, as anther writer put it, with reference to Brother Daniel, "'You actually sued to be known as a Jew? Give me your hand, brother, and welcome aboard." $I d$.

129. Asher Maoz, Who is a Jew? Much Ado About Nothing, in JEWISH LAW Association STUDIES XI: LAW, JUDICIAL POLICY, AND JEWISH IDENTITY IN THE STATE OF ISRAEL 75, 111 (Daniel B. Sinclair ed., 2000).

130. Amnon Rubenstein, The State of Israel as a Jewish State, in JEWISH LAW ASSOCIATION STUDIES XI: LAW, JUDICIAL POLICY, AND JEWISH IDENTITY IN THE STATE OF ISRAEL. 17, 18 (Daniel B. Sinclair ed., 2000). Ben-Gurion's opposition to defining "Jew" halakhically for purposes of the Law of Return was probably "based on his desire for new immigrants to settle in Israel." OSCAR KRAINES, THE IMPOSSIBle DilemMA: Who IS A JEW IN THE STATE OF ISRAEL 2 (1976). As early as the 1940s, Ben-Gurion had supported free aliyah to "impede the possibility of an anti-Zionist solution to the Palestine question upon the end of the mandate." Gavison, supra note 63, at 22. Ben-Gurion's view gained consensus after World War II. Id. And in the context of the military threats the state faced in its first years, tuming away prospective immigrants who probably had some connection to the Jewish people and who wished to help may have seemed rather foolish. 
the omission was intentional ${ }^{131}$ and others claim that the omission allowed individuals who self-identify as Jews but who were not halakhically Jewish to "throw in their lot with Israel." 132 Still others claim that a halakhic definition was universally assumed, so that any definition would have been redundant ${ }^{133}$ (though this seems difficult to square with the Knesset's rejection of, and Ben-Gurion's robust opposition to, Agudat Israel's proposed amendment).

\section{WHO IS A JEW?}

"From the year 70 C.E. when the ancient State of Israel was destroyed by the Romans until the establishment of the modern State of Israel in 1948 the question 'Who Is a Jew?' was hardly ever posed." 34 "In the face of the Crusader, the Cossack, and the Nazi, it was all the Jew could do merely to maintain his identity.... [T] he emergence of the state has radically changed the character of the problem."135

"The term 'Jew' appears in various pieces of legislation: ss. 1, 2, 4A and 4B of the Law of Return; s. 3A(b) of the Population Registry Law 1965; the Rabbinical Courts Jurisdiction (Marriage and Divorce) Law 1953, etc." 136 And with respect to these, and other, laws, "[t]he question of 'who is a Jew' has been the subject of endless, well-known discussions in Israel." "137 Some of the Supreme Court's decisions on this subject have "had strong political repercussions." 138 The issue has more than once led to a cabinet crisis. ${ }^{139}$

The recurrence of the problem is hardly surprising. While it had always had a general relevance-increased somewhat by the growing secularization of European Jewry in the wake of the Haskalah - the emergence of the State of Israel as an independent

131. Amnon Rubenstein, Who's a Jew and Other Woes, ENCOUNTER 84, 86 (Mar. 1971).

132. Sinclair, supra note 12 , at 3-4.

133. Id.

134. KRAINES, supra note 130 , at 1 .

135. Aharon Lichtenstein, Brother Daniel and the Jewish Fraternity, 12 JUDAISM 260, 261 (Summer 1963). See also ABRAMOV, supra note 13, at 271 ("The question of what or who a Jew is did not arise until the end of the eighteenth century, when the advent of Emancipation led to a revaluation of the nature and essence of Judaism.").

136. Rubenstein, supra note 130 , at 17.

137. Klein, supra note 115 , at 58. See also ABRAMOV, supra note 13, at 270; Ginossar, supra note 115 , at 264 ("Few internal problems of Israel have aroused such heated and widespread controversy, as that of defining the term 'Jew").); Lichtenstein, supra note 135, at 260 ("Who is a Jew?' Twice within recent years this troublesome question has been a matter of public Jewish concern."); Perez, supra note 115, at 61 ("The disagreement about "who is a Jew' is one of the biggest controversies in Israel."); Shava, supra note 14, at 140 ("The question 'Who is a Jew?' raises a thomy problem with which the Israeli public and the Knesset has been much preoccupied for some twenty years."). But see JACOBSON, supra note 78, at 56 ("For most Israelis, the issue of 'Who is a Jew' seems about as interesting as the question 'Who is a Sagittarius?'").

138. Englard, supra note 7 , at 190.

139. Shava, supra note 14 , at 140 . 
socio-political entity, defined by fixed geographical bounds, has lent its treatment a rather different and generally sharper character. ${ }^{140}$

Crucially, the discussion is framed by the traditional Orthodox understanding of who constitutes the Jewish people. "By the emergence of rabbinic Judaism in the late Second Temple period, anyone born to a Jewish mother was automatically considered a Jew."141 And even now, "[t]he religious definition of a Jew refers exclusively to two alternative elements: either the Jewishness of the individual's mother or his personal conversion to Judaism." 142 Recently, "[t]he fact that emphasis was placed on the origin of a person and that his beliefs were ignored has proved a source of furious arguments and sharp accusations." 143

One focus of particular difficulty in this respect is the status of "apostates" under Jewish law, particularly "apostates" to Christianity because of the different way in which Christianity defines the Church, and the fact that belonging to community that defines itself by a common belief is not necessarily in conflict with simultaneously belonging to another community that defines itself by common ancestry.

The prevailing view ${ }^{144}$ is that " $[\mathrm{u}]$ nder halacha..., an apostate is regarded as a Jew, but all rights and privileges accorded a Jew are, so to speak, suspended." "145 But "[t]he apostate's rejection... does not necessarily imply, however, that ... he is considered a Gentile." ${ }^{146}$ In the view of Orthodox Judaism a converted Jew, hated and despised as he may be, is nevertheless a Jew. "Judaism, like some nationalities, is a club which one can join but from which no one can escape."147

However, "[t]he premise that a person born to a Jewish mother who

140. Lichtenstein, supra note 135 , at 260.

141. Ruth Langer, Jewish Understandings of the Religious Other, 64 THEOLOGICAL STUD. 255, 258 (2003). See also Benjamin Akzin, Who Is a Jew? A Hard Case, 5 ISRAEL L. REV. 259, 261 (1970) ("Sharing with Roman law the realistic view that mater semper certa est, Jewish religious law views descent from a Jewish mother as decisive in this connection.").

142. Englard, supra note 7, at 194.

143. Rubenstein, supra note 130 , at 18 . For a recent example, see Petty, supra note 6 , at 120-35 (discussing the $J F S$ case in the U.K. Supreme Court).

144. In addition to the majority of the Orthodox movement, both the Reform and Conservative movements in the United States have formally adopted this position as well. See Drifing Apostate, CONTEMPORARY AMERICAN REFORM RESPONSA (July 1986), http://ccarnet.org/responsa/carr-105107/ (last visited May 1, 2014); Apostate in the Synagogue, TESHUVOT FOR THE NINETIES: REFORM JUDAISM'S ANSWERS TO TODAY'S DILEMMAS, http://ccarnet.org/responsa/tfn-no-5753-13-81-85/ (last visited May 1, 2014); Gerald L. Zelizer, The Return of Second Generation Apostates (June 14, 1995), http://www.rabbinicalassembly.org/sites/default/files/public/halakhah/teshuvot/19912000/zelizer_apos tates.pdf (last visited May 1, 2014) ; Kassel Abelson \& Reuven Hammer, The Status of Messianic Jews (Oct. 23, 2012), http://www.rabbinicalassembly.org/sites/default/files/public/halakhah/teshuvot/2011-2020/abelsonhammer-messianic-jews.pdf (last visited May 1, 2014).

145. Slovenko, supra note 118, at 15. See also Lichtenstein, supra note 135, at 263 ("Halachically, a meshumad is barred from fulfilling certain tasks.").

146. Lichtenstein, supra note 135 , at 263.

147. Rubenstein, supra note 131 , at 86 . 
converts to Christianity remains halackhically a Jew (even if an apostate) is not universally shared." "A "A baptized Jew is known in Hebrew, especially in medieval parlance, as 'meshummad' meaning an 'extinct' one. His close relatives had to undergo for him the mourning rites for the deceased... . [F]or the nation, he was 'dead and buried." 149 "The meshummad was regarded as worse than a thief; he was regarded as the lowest kind of creature." 150

Aharon Lichtenstein, an Orthodox rabbi, has noted the complexity of this status. "'Who is a Jew?' ... admits of no single answer. A meshummad - of what type? A Jew-for what purpose?"151 Lichtenstein maintains that there is a "Halachic principle that an apostate can become a Gentile and that Jewishness is not an absolutely irrevocable status."152 And, as will become apparent in the pages to follow, Justice Landau is similarly convinced. ${ }^{153}$

But apart from the halakhic view of things, "a significant proportion of Israeli society . . . defines its Jewishness in secular rather than halakhic terms ... [and] it is natural that secular Israelis should seek a legal definition which is inclusive of their non-halakhic ideology." 154 Although there are "relatively few cases where a gap between the two concepts created a practical problem," 155 several of the "most famous cases in Israeli judicial history center on the question of who is a Jew."156

\section{A. Cases and Legislation}

Three seminal cases have tested the bounds of who is considered a Jew under Israeli civil law. The first, that of Oswald Rufeisen (later, Brother Daniel) concerns the right of a man, born and raised in the Jewish community in what became Poland, who performed heroic deeds during World War II, and who was persecuted as a Jew, but who later also became a Catholic monk and priest, to return to Israel under the Law of

148. Shava, supra note 14, at 142 n.20 (citing S. Meron, Apostate: Jew or Person of Dual Religion, 23 HAPRAKLIT 164 (1967), and A.H. SHAKI, WHO IS A JEW IN THE LAWS OF THE STATE OF ISRAEL 154-169 (1976) [Heb.]); see generally Lichtenstein, supra note 135 (suggesting Jewish status may be lost through total alienation from the Jewish community).

149. Slovenko, supra note 118 , at 15 .

150. Id.

151. Lichtenstein, supra note 135 , at 262 .

152. Id. at 266. As he explained: "[t]here is an apostasy not of action but of person, an estrangement manifested not merely by the commission of various sins but by the complete severance of personal bonds with Jewry; by total alienation from the Jewish people and its history as a spiritual and physical community; and finally, by thorough assimilation into the mainstream of Gentile society. Such persons are not simply disqualified because of some apostate act. Nor are they merely treated as if they were foreign. They are- 'They have betrayed God, for they have begotten strange children.' . . There is, then, a point beyond which the apostate cannot go and yet remain a Jew." Id.

153. Jackson, supra note 113 , at 123.

154. Sinclair, supra note 12 , at 1 .

155. Englard, supra note 7 , at 194.

156. JACOBSON, supra note 78 , at 63 . 
Return. "The decision of the Court-together with Brother Daniel's paradoxical identification of himself as a Jew-... brought into sharp focus certain questions of Jewish identity that continue to be vexing both in Israel and throughout the Diaspora." 157

The second addresses the right of an officer in the Israeli Navy, who married a non-Jewish woman, to have his children registered as Jews on their identity cards. The third, following a legislative amendment, addresses whether Jews who have adopted a belief in Jesus as the Messiah, but who have not been baptized or otherwise formally affiliated themselves with Christianity remain Jews for purposes of the Law of Return. A close examination of these cases offers a view into how the Supreme Court of Israel understands who is a Jew, and thus what constitutes "Judaism," and more broadly "religion," under law.

\section{Rufeisen (Brother Daniel)}

"The story of Oswald Rufeisen is an extraordinary one in itself."158 Some of Rufeisen's background is brought out in the Supreme Court's opinions. But for a full account, I rely heavily here on Nechama Tec's biography of Rufeisen because his persecution during the Holocaust bears on one central reason why the State of Israel was created: to provide a refuge for Jews. A thorough account of Rufeisen's experience is therefore relevant to the ultimate outcome of his court case. In any event, it is indeed extraordinary. As one reviewer put it, "[w]ere [Tec's] book not so heavily documented, one would be inclined to dismiss it as the musings of an incredibly creative mind. Were it a novel, one might be inclined to suggest that [she] has strayed into the realm of the improbable."159

\section{a. Becoming Brother Daniel}

Oswald Rufeisen, a short man with unimposing features and a humble demeanor who "liked to do favors for people," 160 was born in Zadziele, a village in the south of what is now Poland. ${ }^{161}$ Rufeisen's father had fought for the Germans in World War I. That, along with the high status that the German language carried in Poland at the time meant that German was Rufeisen's primary language at home. Unusually for Jews of limited means, Rufeisen finished school in 1939 and was awarded his matura. ${ }^{162}$ His education and his fluency in German would both prove invaluable.

In September 1939, the Germans invaded Poland. Rufeisen, his brother,

\footnotetext{
157. Marc Galanter, A Dissent on Brother Daniel, COMMENTARY 10, 10 (July 1963).

158. Jackson, supra note 113 at 115.

159. Deborah E. Lipstadt, Book Review, 97 AM. HIST. REv. 160, 160 (1992).

160. NeChama TEC, IN THE LION'S Den: THE LIFE OF OSWALD RuFEISEN vii-viii (1990).

161. Id. at 3.

162. Id. at 14 .
} 
and their parents fled north before the parents (his mother already ill) gave Rufeisen and his brother their money and instructed them to continue on without them. The brothers would never see their parents again. ${ }^{163}$

Rufeisen first went to Lviv, in what is now Ukraine, where about one hundred members of his Zionist youth group, Akiva, had found refuge. From there, Rufeisen made his way to Vilna (now Vilnius, Lithuania) where he remained for a time. ${ }^{164}$ On June 22, 1941, the Germans bombed Vilna. After initially taking shelter in a basement, Rufeisen, without saying a word to anyone, went out into the streets to join a makeshift search-and-rescue team while the bombs continued to fall. ${ }^{165}$

Eventually Vilna fell to the Nazis, and Rufeisen was detained. Many of his companions at this time were murdered, ${ }^{166}$ but Rufeisen was spared because he had learned the shoemaking trade as a youth and the Nazis had confiscated a large quantity of leather that required skilled labor he could provide. Additionally, because Rufeisen spoke German, he was appointed the representative for this group of forced laborers, and because of his education (which was far in excess of most shoemakers) he was also appointed the shop foreman, taking orders and doing the bookkeeping. ${ }^{167}$

When feeding Rufeisen and the other prisoners became too costly, the Nazis left them to fend for themselves, but permitted them to live unconfined. One day, a man Rufeisen passed in the street asked if Rufeisen would like to come work on his farm, where he would be safe. Rufeisen hesitated initially, but after seeing a crowd being led off to their deaths, he resolved to live the rest of the war as a gentile. He knew he could pass as a Pole, spoke good German, and had a school identification card that did not identify him as a Jew. He invented a story that he was half-Polish and half-German, and that his parents were dead. ${ }^{168}$

Just before the supply of leather ran out, and his fellow leather-workers were all murdered, Rufeisen walked the six miles to the man's farm. He remained there for several months, but when it became too dangerous to remain near Vilna, he went East to the home of the farmer's brother, in Belorussia. ${ }^{169}$ The Germans in that area were short of translators, and it was suggested that he go work for them. ${ }^{170}$

The head of the regional police dragooned him into the police force to serve as a personal assistant and translator, and he shortly thereafter was

\footnotetext{
163. Id. at 15 .

164. Id. at 16-17.

165. Id. at 26-27.

166. Id. at $35-37$.

167. Id. at 38 .

168. Id. at $45-47$.

169. Id. at $47-61$

170. Id. at $61-62$
} 
made the secretary of the regional police. ${ }^{171}$ Once established, Rufeisen sought and was granted an official identification card. He could have claimed to be of German ethnicity (volksdeutsche) based on his fictitious German father, and this would have carried certain advantages; Rufeisen concluded that it might also raise additional questions and suspicions. Instead, he claimed Polish ethnicity, which (since German ethnicity was an option open to him) resulted in locals viewing him as a patriot and a principled man who valued his Polish heritage above material gain. ${ }^{172}$

While working for the regional police in Mir, Rufeisen had special access to information because of his language skills and education, and his position as secretary. ${ }^{173}$ When he recognized a Jew he knew from Vilna, he began to construct a network to provide information to the Jews in the area. When Rufeisen learned that the Mir ghetto was to be completely liquidated on a particular date, he organized an "anti-partisan raid" that took the would-be persecutors in the wrong direction, to fight Russian partisans that did not exist, leaving time for those in the ghetto to escape. Although Rufeisen had also armed the Jews in the ghetto, fewer than 300 escaped successfully. ${ }^{174}$

After the raid, Rufeisen was denounced to his superiors. ${ }^{175} \mathrm{He}$ admitted that he was a Jew and started running. He found shelter in a convent, where he read the New Testament and various Carmelite publications. ${ }^{176}$ Less than three weeks later, Rufeisen asked the mother superior to baptize him. ${ }^{177} \mathrm{He}$ felt that it was not a rejection of his Jewish heritage; he wanted a stronger connection to the New Testament, which he read as a Jewish document. In particular, the account of the death and resurrection of Jesus helped him to cope with the horrors of the Holocaust. ${ }^{178} \mathrm{He}$ had less interest in the Church as an institution and the writings of Catholic theologians. ${ }^{179}$

When he felt he might be placing the nuns at risk, Rufeisen left the convent and joined partisan militants. ${ }^{180}$ Initially believing Rufeisen to be a German spy, the partisans condemned him to death, but he was saved by one of the Jews of Mir who had been able to escape the ghetto on account of Rufeisen's assistance. ${ }^{181}$ After the Russians forced a German retreat and reclaimed the area, they indicated that they had no interest in detaining

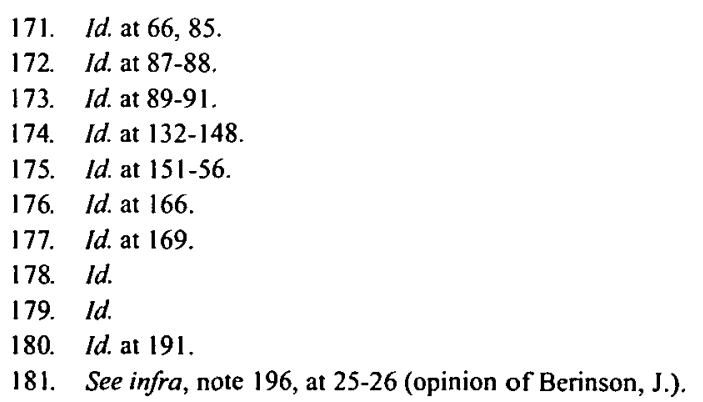


Rufeisen despite his former employment with the Germans. Rufeisen then made his way to Czerna where he applied to join a Carmelite monastery. ${ }^{182} \mathrm{He}$ chose the Carmelites deliberately because he knew from his time with the nuns they had a chapter in Israel. ${ }^{183}$ After a period of preparation, Rufeisen took his final vows as a monk in 1949 at age $27 .{ }^{184}$ He was later asked to prepare for the priesthood, and became a priest as well. ${ }^{185}$

After many unsuccessful attempts, the Carmelites gave him permission to relocate to Israel. But when he met with the Israeli ambassador, he was told that he could not emigrate to Israel as a Jew because he was a Christian monk, and that the determination of Jewish status under Israeli law was a contentious point in Israel at the time. ${ }^{186}$ Instead, Rufeisen was granted a one-year visa based on his brother's residency there. ${ }^{187} \mathrm{He}$ entered the Carmelite monastery on Mt. Carmel in Haifa, to serve as a counselor to members of mixed marriages. ${ }^{188}$

In Israel, Rufeisen was received warmly by those he knew during the war, even if they were unhappy or disappointed by his conversion to Christianity. He was invited to family gatherings by his brother and treated as a close friend by many of his former Akiva companions. But, while loved dearly, he was also an outsider. ${ }^{189}$ Not recognized as a Jew by the Israeli authorities before leaving Poland, he applied for an oleh's certificate after arriving, and was refused.

\section{b. Before the Supreme Court}

After receiving permission from the relevant authorities in Rome, Rufeisen sought injunctive relief against the Minister of the Interior before the Supreme Court, sitting as the High Court of Justice. He claimed that because, despite his conversion, he remained a Jew as a matter of halakha, he was entitled to residency and citizenship under the Law of Return. "Under halachic law he was without question a Jew, born of a Jewish mother. The tradition was 'once a Jew, always a Jew': you could be a wicked Jew, a deserting Jew, a treacherous Jew, but a Jew you remained." 190

In Rufeisen, the Court had to decide "whether the term 'Jew' in the Law

182. TEC, supra note 160 , at 207.

183. See infra, note 196, at 26 (opinion of Berinson, J.) (quoting Rufeisen's passport application).

184. TEC, supra note 160 , at 213 .

185. Id.

186. Id. at 220

187. Id. at 221

188. Slovenko, supra note 118 , at 3 . Some Orthodox communities concluded that Rufeisen had come to Israel to convert Jews to Christianity. TEC, supra note 160, at 225.

189. TEC, supra note 160 , at 224.

190. S. Clement Leslie, THE Rift IN ISRaEl: Religious authority and Secular DEMOCRACY 38 (1971). 
of Return carried a religious-halakhic, or secular meaning." 191 One observer suggested that "[f]rom the opening argument until the last word of the judgment, the courtroom was less the scene of legal debate than a pageant of 2,000 years of Jewish history, philosophy, and religious thought; for the judges were being called upon to define-although in the admittedly specific context of the Law of Return-what the broad concept of Jewishness meant."192 "Appearing before the Supreme Court in brown habit and sandals," Rufeisen spoke of "the sufferings and ordeals he endured as a Jew and the pride he felt in being Jewish and in the State of Israel." 193

But suffering and pride were not enough to carry the day. " $T$ The Supreme Court ruled that an individual who was born a Jew but converted to Catholicism and became a monk was not entitled to benefit from the Law of Return and could not be registered in the population register as being of Jewish nationality." 194 On Rufeisen's identity card, under the heading of "nationality," it says not "Jewish," but "Not clear."195

The Court, composed of five justices, produced four separate opinions. ${ }^{196}$ All members of the Court agreed that the Law of Return was a secular law; there was no disagreement that the halakhic definition did not govern the interpretation. ${ }^{197}$ The Court held that because "the Law of Return is secular legislation,... [it] must be interpreted according to secular principles." 198 Focusing on the need for a secular definition of "Jew" for a secular piece of legislation "enable[d] [the Court] expressly to affirm the nontheocratic nature of the state." 199 And "since the Law of Return contained no definition of 'Jew,' ordinary usage, 'the language of men," the Court determined, "must be the governing factor." 200

191. Shava, supra note 14 , at 142.

192. Slovenko, supra note 118 , at 5 (internal quotation omitted).

193. KRAINES, supra note 130 , at 24.

194. Klein, supra note 115 , at 59.

195. TEC, supra note 160 , at 231. See also Rubenstein, supra note 131, at 88 n.6 (noting that Rufeisen was allowed to settle in Israel and acquire Israeli citizenship, but not under the Law of Return as a Jew); Klein, supra note 115 , at 59 ("Rufeisen did actually apply for and was granted Israeli nationality through the naturalization process.").

196. HCJ 72/62 Rufeisen v. Minister of the Interior, 16 PD 2428 [1962] (Isr.), translated in SEleCted JuDGMENTS OF THE SUPREME COURT OF ISRAEL, SPECIAL VOLUME 1-34 (Asher Felix Landau ed., 1971) [hereinafter Rufeisen]. Justice Manny concurred in the opinions of Justices Silberg and Landau. Id. at 24.

197. Sinclair, supra note 12, at 5; Shava, supra note 14, at 142-43 (noting that "the majority opinion espoused an objective secular test- 'in common parlance' and 'as used as the present time by the people' [while] H. Cohn J. favored the adoption of a subjective secular test") (citations omitted).

198. Slovenko, supra note 118 , at 15.

199. JACOBSON, supra note 78 , at 64 .

200. LESLIE, supra note 190 , at 39. See also JACOBSON, supra note 78 , at 65 (noting that for the majority, "the secular meaning of the term 'Jew' in the Law of Return is to be derived from the common understanding of the 'ordinary simple Jew."'); L.C. Green, Book Review, 71 AM. J. INT'L L. 175,191 (1977) (Under the Law of Return, "Jew' has the secular national meaning attributed to it in common parlance."). 
The Justices split, however, on how to determine the ordinary, secular meaning of the word "Jew." The majority favored a combination of what they viewed as common understandings used in everyday language coupled with some notion of traditional bounds of collective identity. ${ }^{201}$ Applying this test, the Court concluded that the secular view "treated conversion as decisive and excluded the convert from the Jewish community."202 Justice Cohn, dissenting, favored a wholly subjective approach based on the individual's preference. ${ }^{203}$

Justice Silberg began, after noting Rufeisen's deeds during the Holocaust, to review the religious law on the matter, and concluded that the Jewishness of a convert is "indivisible and absolute." 204 But whereas the term "Jew" means a Jew according to Jewish law under the Rabbinical Courts Jurisdiction (Marriage and Divorce) Law, Silberg saw the same word as bearing a "secular meaning, as it is usually understood in common parlance - and this I emphasize - by the ordinary simple Jew." ${ }^{205} \mathrm{He}$ explained that the purpose of defining the jurisdiction of the rabbinical courts is to make Jewish law applicable to Jews, and defining Jews any other way than by halakha would defeat the purpose of the law. ${ }^{206}$ On the other hand, "[f]or all its immense historical importance, [the Law of Return] is a secular law, and in the absence of definition either in the statute itself or in the decided cases, we must interpret its terms according to their ordinary meaning." 207 The question then, is whether the "ordinary Jewish meaning of the term 'Jew' . . . include[s] a Jew who has become a Christian?"208

Silberg held the answer was a clear "no."209 "Justice Silberg, writing for the majority, concluded that the communal understanding of the term does not include a Jew who has become a Christian." 210 He suggested that "Jew" and "Christian" are incompatible statuses." "The deeply rooted belief that Jew and Christian are contradictory terms is shared alike by simple people and scholars."212 On this view, Rufeisen "has deserted, not merely lapsed." 213 Framing the issue of return in the context of Zionism, Silberg explains that it is the Jewish people's "historic culture as Jews

\footnotetext{
201. Sinclair, supra note 12 , at 5; Shava, supra note 14, at 142-43.

202. Rubenstein, supra note 131 , at 88 .

203. Sinclair, supra note 12, at 5; Shava, supra note 14, at 142-43.

204. Rufeisen, supra note 196, at 2-10 (opinion of Silberg, J.).

205. Id. at 10.

206. Id.

207. Id.

208. Id.

209. Id. at 11 .

210. JACOBSON, supra note 78 , at 66 .

211. Jackson, supra note 113, at 120.

212. Rufeisen, supra note 196, at 12 (opinion of Silberg, J.).

213. Jackson, supra note 113 , at 122.
} 
which entitles them to the land." ${ }^{214}$ Silberg wrote:

Whether he is religious, non-religious or anti-religious, the Jew living in Israel is bound, willingly or unwillingly, by an umbilical cord to historical Judaism from which he draws his language and its idiom, whose festivals are his own to celebrate, and whose great thinkers and spiritual heroes-not the least of whom are the martyrs of 1096 and those who perished at the stake in Spain-nourish his national pride. ${ }^{215}$

Because the adoption of Christianity is inconsistent with the maintenance of Jewish cultural ties, Silberg concluded that Rufeisen had forfeited his right to return to Israel as a member of the Jewish people. ${ }^{216}$

Justice Landau joined in Silberg's opinion and added some commentary of his own. ${ }^{217}$ "[T] he main thrust of the judgment of Landau J. is to stress the importance for this case of the manner of construction of Jewish identity by the founders of Zionism." ${ }^{218} \mathrm{He}$ suggested that the position of halakha toward the convert was not one of forbearance, but of contempt, and thus Rufeisen should not have invoked it in aid of his cause. ${ }^{219}$ In any event, he agreed that the question was not to be decided by religious law because the Law of Return "is a secular Law of the State of Israel." 220

Looking to the Zionist roots of the state, Landau noted that Herzl had refused admission to the Zionist Organization of a Jew who had converted to Christianity, ${ }^{221}$ and that Ahad Haam ${ }^{222}$ rejected the notion that even an entirely secular Israeli could deny the influence and importance of historical Jewish practice on its current constitution - to deny that past would be to deny what made Jewish nationalism Jewish. ${ }^{223}$ Thus, Landau concluded that "[a] Jew who, by changing his religion, cuts himself off from the national past of his people ceases thereby to be a Jew in the national sense to which the Law of Return gives expression."224 "The stress placed by Landau J. upon identification with the religious sentiment of the past is not based upon any assertion of the religious value of the past, but rather upon its sociological function in constituting group

214. Id. It has been suggested that the case was regarded as a cause célèbre, in part, because it "pose[d] questions, not only about Jewish identity, but also about Zionism, and about the relations between them." Id. at 120 .

215. Rufeisen, supra note 196, at 11 (opinion of Silberg, J.).

216. See Jackson, supra note 113 , at 122.

217. Rufeisen, supra note 196, at 18-19 (opinion of Landau, J.).

218. Jackson, supra note 113 , at 120.

219. Rufeisen, supra note 196, at 19 (opinion of Landau, J.).

220. Id.

221. Id. at 20.

222. For more on the intellectual contribution of Ahad Haam to Zionism, see BATNITZKY, supra note 22 , at $155-60$.

223. Rufeisen, supra note 196, at 20-21 (opinion of Landau, J.).

224. Id. at 22 . 
identity." 225 In becoming a Christian, Landau, J., concluded that Rufeisen "excluded himself from the common fate of the Jewish people and has linked his destiny to other forces whose precepts he honours both in thought and in observance." 226

Justice Berinson likewise "explained the popular view as based upon the (mutual) denial of community which occurs when a Jew converts to another religion."227 And, like Silberg, Berinson took the relevant understanding of "Jew" to be that of the man on the street. ${ }^{228}$

Berinson began by observing, almost wryly, that the "usual case" of conversion-"for reasons to which we have become accustomed"assimilation, mixed marriages, improvement of social or material status, public career, etc., do not apply; "material comforts and worldly pleasures" hold no attraction for the monk. ${ }^{229}$ After summarizing the particulars of Rufeisen's conduct during the War and his attempts to immigrate to Israel, ${ }^{230}$ Berinson noted that he was not free to simply grant the request, which he would if he were so empowered. ${ }^{231} \mathrm{He}$ noted that the parties agreed that the Law of Return must be given a "secular-national, and not a religious connotation," but diverged on what that connotation was. ${ }^{232} \mathrm{He}$ further conceded that had Rufeisen been captured by the Nazis after his conversion, the conversion would have made no difference "and he would have fallen victim to them as a Jew." ${ }^{, 233}$ Interestingly, Berinson suggests that "had he declared that he believed in Buddhism which does not require a change of religion and lived as a Buddhist monk, he would apparently have been recognized as a Jew. Thus as a Buddhist monk yes, but as a Christian monk no!"234 Berinson also maintains that Ahad Haam would not have viewed a Jew who converted to another religion, but who in all other respects was deeply Zionist, as outside the bounds of the Jewish people. ${ }^{235}$

But despite this, Berinson concluded that "[t]he people themselves... have decided otherwise... . For them a Jew who has embraced another religion has withdrawn himself not only from the Jewish faith but also from the Jewish nation and has no place in the Jewish community." ${ }^{236}$ The common understanding of the Jewish people is that "a Jew and a Christian

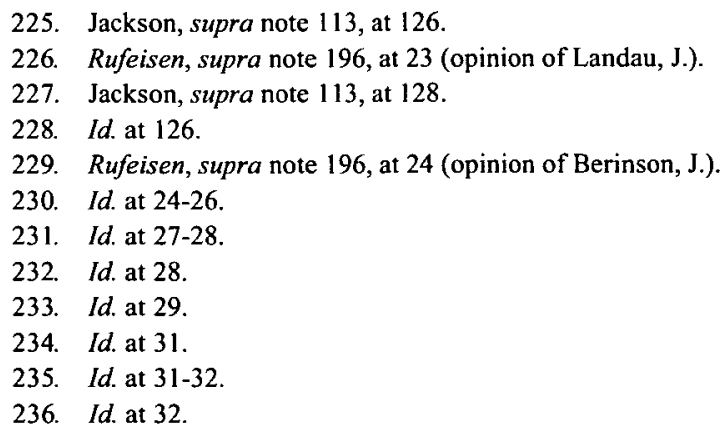


cannot reside in one person" 237 because of "the (mutual) denial of community which occurs when a Jew converts to another religion. ${ }^{.238}$ It was this "popular meaning" that Berinson believed the Knesset intended when it enacted the Law of Return. ${ }^{239}$ Justice Berinson noted that even as early as 1947, the position of the Jewish Agency, in testimony given before the United Nations Special Committee for Palestine, was that formal conversion to another religion would exclude one from the Jewish people for political purposes. ${ }^{240}$

Justice Cohn dissented. ${ }^{21} \mathrm{He}$ agreed that according to Jewish religious law a converted Jew remains a Jew, agreed that the Law of Return (and related registration laws) should not be construed according to Jewish religious law, and agreed that the Law of Return should not be construed to negate the principles on which the State of Israel was founded. ${ }^{242}$ But he differed on whether permitting Rufeisen to become an Israeli citizen under the Law of Return would do so. Instead, he would permit anyone who declared in good faith that he was a Jew the privileges granted by the Law of Return, regardless of whether the applicant had no other religion. ${ }^{243}$ Just as Jewish religious law cannot claim to be the proper lens through which to view the Law of Return's ambiguous terms, Cohn held that it would be equally improper to consider the religious law of any other religion, as his colleagues had done in examining the effect of Rufeisen's participation in Catholic sacraments, in determining who is a Jew for purposes of secular legislation. ${ }^{244}$

Rufeisen's aim in going to court was to establish a precedent. ${ }^{245} \mathrm{He}$ was offered immediate citizenship by the Minister of the Interior if he would drop the case, but refused. ${ }^{246}$ Later, Rufeisen regretted having taken the case to court. He suggested, "had my position been accepted this would have created a revolution in conventional concepts."247

The Rufeisen decision, although its result was broadly applauded in Israel, was not without its critics and detractors. For example, by tying the legal definition of "Jew" to common understanding, some complained that the "majority's definition was both vague and impermanent." 248 It also turned on the supposition that "a single 'common' meaning [of 'Jew']

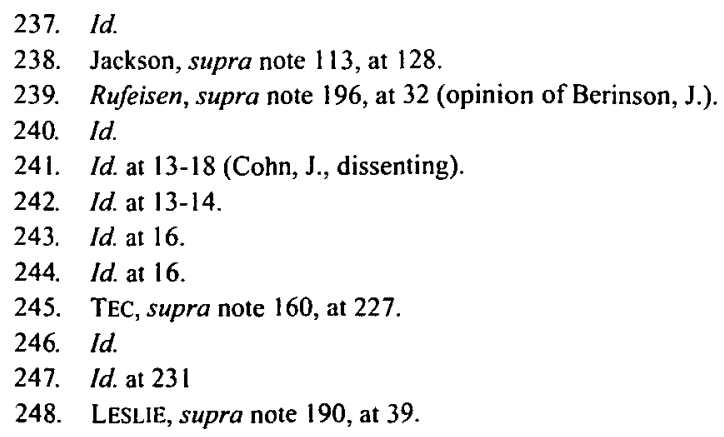


exists and can be found."249 And even assuming such a definition can be discerned, a further question remains with respect to who is permitted to offer an answer in order to determine the common understanding. "Israelis? If so, only Jewish Israelis, or, since this is a secular law, all Israelis? The Diaspora as well? Contemporary Jews or those throughout history?"250

Moreover, apart from problems of determining who is a Jew according to a common understanding, the majority's reasoning with respect to collective identity "rests on the theory that Jewishness and Christianity are incompatible." 251 And this theory rests in turn on the premise that while irreligion does not vitiate one's connection to the Jewish people, conversion to Christianity does. ${ }^{252}$ This conception of Jewishness "tends to visualize all of Jewish history in relation to Christianity." 253 Finally, the decision "in no way answers the question of who is a Jew under the Law of Return; it only asserts that an apostate such as Brother Daniel is not a Jew." 254

\section{Shalit}

The next case was not long in coming. The use of halakhic standards to determine who is a Jew for purposes of registration was a longstanding controversy. Initially there may have been a tacit understanding that halakhic standards governed, but as early assumptions that determination of Jewish status would be a simple matter turned out to be incorrect, any understanding that previously existed began to break down before the state was a decade old.

"On March 10, 1958, Minister of the Interior Bar-Yehuda from the Labour Party, issued new guidelines on registration, whereby 'a person who declares himself to be Jewish, in good faith, should be registered as Jewish.' . . . As a reaction to those guidelines all the religious parties left the Coalition." ${ }^{255}$ The prime minister established a committee to study the situation, and the committee consulted eminent scholars and public

249. Galanter, supra note 157 , at 11.

250. Id.

251. Id. at 15 .

252. Id.

253. Id.

254. JACOBSON, supra note 78 , at 66 .

255. Rubenstein, supra note 130 , at 20; Lawrence S. Nesis, Who is a Jew?, 4 MANITOBA L.J. 53, 61 (1970). Bar-Yehuda's guidelines formalized the existing practice of accepting a declaration that one was a Jew as sufficient for registration. For example, in 1953, Abraham Samuelov, a Catholic Monk, was registered as Jewish on the basis of his own representation that he was a Jew of the Catholic faith. Z. Warhaftig, Who is a Jew?, in JEWISH LAW ASSOCIATION STUDIES XI: LAW, JUdiCIAL POliCY, AND JEWISH IDENTITY IN THE STATE OF ISRAEL 23, 25 (Daniel B. Sinclair ed., 2000). However, under directives dating to 1956 , children of mixed marriages were to be registered under their mother's religion. Nesis, supra, at 62. 
figures. ${ }^{256}$ A significant majority of those consulted favored the halakhic definition. ${ }^{257}$ "Forty-five replies were received, and of them, thirty-seven scholars argued in favor of the halakhic test.... Only three replies supported the view that the meaning of ' $\mathrm{Jew}$ ' in a secular and in a religious context were different." ${ }^{258}$ The prime minister then assigned a member of a religious party to be Minister of the Interior and henceforth halakhic criteria were applied to registration as a matter of policy. ${ }^{259}$

Benjamin (or Binyamin) Shalit was born in Haifa in 1935. ${ }^{260}$ While studying in Edinburgh, he met and married his wife Anne (or possibly Ann), who was not Jewish and who did not convert to Judaism. ${ }^{261}$ Both husband and wife were non-believers, and their marriage was a civil one. ${ }^{262}$ The couple returned to Israel in 1960 , Anne became a naturalized citizen, and together they had a son in 1964 and a daughter in $1967 .{ }^{263}$ In the meantime, Shalit, a psychologist, had become an officer in the Israeli Navy. ${ }^{264}$

The Shalits registered their children in accordance with the Registration of Inhabitants Ordinance 1949 (the forerunner to the Population Registry Law 1965). ${ }^{265}$ "Registration, as such, does not confer any benefit upon the persons registered, nor does it alter their legal status in any way. It means nothing beyond the fact of registration." 266 The details to be registered included the children's dat (literally "law" but connoting "religion") and le $\mathrm{um}^{267} \mathrm{Le}{ }^{2} \mathrm{um}$ is "an untranslatable term which was probably derived from Central and Eastern Europe. It means something akin to 'peoplehood' and designates a common ethnic, cultural, and linguistic

256. Sinclair, supra note 12 , at 4 .

257. Id. at 4-5; ABRAMOV, supra note 13, at 292.

258. Rubenstein, supra note 130, at 20-21.

259. Sinclair, supra note 12 , at 5 .

260. Nesis, supra note 255 , at 53.

261. Id. Anne was, however, the granddaughter of Sir Patrick Geddes, a Zionist who collaborated with Chaim Weizmann to establish the Hebrew University. See Rubenstein, supra note 131, at 84 .

262. KRAINES, supra note 130 , at 46 ; Nesis, supra note 255, at 53 (noting the Shalits considered themselves atheists).

263. Nesis, supra note 255 , at 53; KRAINES, supra note 130 , at 46

264. Nesis, supra note 255 , at 53; KRAINES, supra note 130 , at 46 . By the time of the Supreme Court's decision in 1970, he had risen to the rank of Lieutenant Commander. Rubenstein, supra note 131, at 84; KRAINES, supra note 130 , at 26.

265. Nesis, supra note 255 , at 60.

266. Rubenstein, supra note 131 , at 84 .

267. Nesis, supra note 255 , at 53 . It should be noted that " $t \mathrm{t}]$ he Hebrew language does not have a word for "religion." Dan, supra note 1, at xxvi. The word dat, which in Modem Hebrew denotes the concept of religion, is a Persian loan-word that entered ancient Hebrew in late biblical times, and which originally referred to simply "law," i.e., the law of the gentile king. Id. at xxvi \& n.5. In Modern Hebrew, however, it denotes "divine law." Id. "[T]he concept, as used today, is a translation from European languages rather than an intrinsic development." Id. As will be explained more fully below, " $[t]$ he use of the term 'religion' in a Jewish context is ... an external imposition rather than an authentic expression of the intrinsic nature of Judaism." Id. at xxviii. 
origin."268 "Ethnic group," "nationality," and "people" have all been used as English translations. ${ }^{269}$

In keeping with their atheistic convictions, the Shalits declined to designate a religion for their son's registration, and listed his le'um as "Jewish." The registration clerk amended the religion to "Father-Jewish, Mother-non-Jewish" and amended the entry for le'um to read "not registered." 270 Later, a different clerk, following new guidance, reversed these designations when the Shalits' daughter was registered. For her, the clerk designated "Father-Jewish, Mother-non-Jewish" under le'um, and "not registered" under religion. ${ }^{271}$

In February 1968, Shalit applied to the Supreme Court to order the Minister of the Interior to register both children as "Jews" under le 'um and "without religion" under dat. ${ }^{272}$ After the first hearing, a special court of five justices was convened, but later, the President of the Court, Justice Agranat, took the unprecedented step of convening the entire court to hear the case. ${ }^{273}$ "As soon as Shalit applied to the Court, the judges sensed that they were dealing with an explosive issue."274 "Both parties were armed mainly with non-legal authorities, invoking the writings of Jewish philosophers, statesmen, and scholars. It was the least legal case ever argued."275

Shalit argued, first, that the registration must be made in accordance with the declaration of the declarant, and that the registration clerk was not authorized to change what was declared. ${ }^{276}$ Second, he maintained that one's le'um is something different from one's religion, and that belonging to the Jewish ethnic group need not be determined halakhically, which

268. Rubenstein, supra note 131 , at 84 . See also id. at $103 \mathrm{n} .1$ (noting near-equivalency with the German concept of Nationalität).

269. Nesis, supra note 255 , at 54.

270. KRAINES, supra note 130 , at 46 .

271. Id. This was in error, and the Minister of the Interior later specified that he was ready to correct the daughter's registration to be identical with the son's. Nesis, supra note 255 , at 55 .

272. KRAINES, supra note 130 , at 46 ; Rubenstein, supra note 131 , at 88.

273. Rubenstein, supra note 131 , at 88 ; Shava, supra note 14 , at 144 . Other sources suggest that the Court at that time had a tenth member who was not on the panel. Gideon Hausner, The Rights of the Individual in Court, 9 ISRAEL L. REV. 477, 490 (1974); KRAINES, supra note 130, at 46. The Supreme Court typically hears cases in panels of three justices. Exceptionally, a panel of five justices may be convened, as happened in Rufeisen. Larger panels have been convened only twice: a panel of seven was seated in HCJ 51/80 Cohen v. Rabbinical High Court of Appeals 35(2) PD 8 [1980] (Isr.), and the panel of nine that heard Shalit has never been replicated. The reason why larger panels are convened so infrequently is the staggering workload of the court. In contrast to most courts of last resort (and especially the Supreme Court of the United States, which exercises almost exclusively discretionary jurisdiction), the Supreme Court of Israel not only hears appeals as of right from most civil and criminal matters, but also acts (in its capacity as the High Court of Justice) as a court of first instance in most public matters. Gidon Sapir, How Should a Court Deal With a Primary Question That the Legislature Seeks to Avoid? The Israeli Controversy Over Who Is a Jew as an Illustration, 39 VAND. J. TRANSNAT'L L. 1233, 1241 n.30, 1242 n.34 (2006).

274. Rubenstein, supra note 131 , at 88 .

275. Id.

276. Nesis, supra note 255 , at 55 . 
could not fully apply to Israeli conditions, but could be evidenced by subjective identification with Jewish-Israeli culture and values. ${ }^{277}$ Shalit asked whether "Kamal Nimri, the terrorist, [would] be regarded as a Jew while my children, who get a Hebrew and Israeli education and who would fight for Israel, [would] be considered as non-Jews?"278 The Attorney General, in response, tied the Jewish religion to the Jewish nation as inseparable elements of Jewish existence, with religion taking primary importance. ${ }^{279}$

In November 1968, after the case had been under consideration for several months, the entire court asked the Government to intervene by deleting the requirement that $l e$ 'um be listed in registration documents. ${ }^{280}$ "The court's plea was brought to the cabinet and rejected in what was later described by one of the judges as 'a summary procedure." 281 It was reported that the rejection was based upon security grounds: le'um is the only way to quickly and easily distinguish between Jews, Arabs, and Druze because dat is not printed on identity cards. ${ }^{282}$

The Shalit majority held by a vote of five-four that le'um, as nationality/ethnicity, need not follow the halakhic view of who belonged to the Jewish people. ${ }^{283}$ And "[s]ince the issue was only registration and not a substantive right such as citizenship, the majority was also prepared to adopt the purely subjective definition advocated by Cohn J. in Rufeisen." 284 The Court ordered the Minister of the Interior to register the

277. Id. See also KRAINES, supra note 130, at 46 ("What Shalit, in effect, was trying to accomplish was to have the Supreme Court declare that there is a Jewish nationality separate from the Jewish religion.").

278. Rubenstein, supra note 131 , at 88 . Nimri was the commander of the Fatah movement in East Jenusalem. See TOM SEGEV, 1967: ISRAEL, THE WAR, AND THE YEAR THAT TRANSFORMED THE MIDDLE EAST 499 (2005) (Jessica Cohen trans., 2007). Nimri's mother was Jewish; his father, an Arab Muslim.

279. Rubenstein, supra note 131, at 88 ; KRAINES, supra note 130 , at 47.

280. Rubenstein, supra note 131 , at $88-89$.

281. Id. at 89.

282. Rubenstein, supra note 131 , at 89 ; Shalit, infra note 283 , at 106 (Kister, J., dissenting). This would confirm Ben-Gurion's 1958 explanation that "[i]n light of our special situation, when there is no practical possibility of a thorough and permanent control of the country's borders to prevent the entry of infiltrators from the hostile neighboring countries, who are a source of grave and constant danger to the peace of the country and its population, it is essential that a legal resident in Israel should be able to identify himself at all times by means of a document supplied by an official authority." Nesis, supra note 255, at 61 (internal quotation omitted). Under the Registry of Inhabitants Ordinance 1949, during times of emergency, every male resident was required to carry his identity card. Id. at 60 .

283. See HCJ 58/68 Shalit v. Minister of the Interior, 23(2) PD 477 [1969] (Isr.), translated in SElected Judgments of THE Supreme COURT of ISRAEl, SPeCial Volume 35-191 (Asher Felix Landau ed., 1971) [hereinafter "Shalit"]. The nine justices produced eight opinions: Justices Sussman, Berinson, Witkon, and Manny agreed (with Manny simply joining in the opinions of Sussman and Cohn) that the primary question concerned the authority of the registration officer; Cohn concurred, but would accord less authority to the registration officer than the other justices in the majority; President of the Supreme Court Agranat, Deputy President Silberg, and Justices Landau and Kister dissented, addressing the question of nationality more directly. See also Green, supra note 200, at 191 .

284. Sinclair, supra note 12, at 7; see also Rubenstein, supra note 131, at 84 ("As legal battles go, the Shalit case was ostensibly marginal."). 
Shalit children as Jews under $l e^{\prime} u m{ }^{285}$ Justice Sussman, delivering the opinion of the Court, explained that "[ $t]$ he determination of the affiliation of an individual to a given religion or a given nation derives principally from the subjective feeling of the person concerned." 286

"Sussman (and even more explicitly, Justice Berinson) underscored the secular orientation of the earlier Court. It is implicit in their opinions that the divisive nature of the issue raised by Shalit effectively removed the last barrier to the adoption of a secular and subjective interpretation." 287 Sussman explained that the registration officer refused to register the Shalit children as Jewish by nationality because the category "embraces ... the norms of Jewish nationality and of the Jewish religion together, and accordingly no person is to be regarded as being of Jewish nationality if the Jewish religion does not regard him as a Jew at all."288 And, in turn, the respondents claimed that the Jewish religion embraced only a person whose mother is Jewish or who has been converted according to religious law, and who is not also a member of another religion. ${ }^{289}$

Sussman disclaimed any suggestion that the Court was determining who was a Jew; rather, he proposed that the only matter before the Court was whether the registration officer was required to register the children in accordance with the instructions of the parents, or whether "they can be justified in their refusal." ${ }^{290}$ Sussman held that the registration officer had not been statutorily authorized to "decide any question," and as a citizen who provides information to the officer in accordance with law is presumed to be stating the truth (unless the statement is clearly false on its face, as an adult wishing to register as a five-year old child). ${ }^{291}$ Sussman explained that while the registration officer was acting in accordance with earlier directives of the Minister of the Interior, they are administrative only, and to the extent they are inconsistent with or extend beyond powers granted by statute, they are invalid. ${ }^{292}$

After noting that the purpose of registration is largely statistical, and that some matters of registration are largely subjective, and therefore the legislative purpose was not effectuated by refusing to register bona fide

285. Rubenstein, supra note 131 , at 89.

286. KRAINES, supra note 130 , at 48.

287. JACOBSON, supra note 78 , at 72.

288. Shalit, supra note 283 , at 64 .

289. Id. It is interesting to note that the respondents asserted the primacy of the halakhic definition, while at the same time narrowing that definition to exclude members of other religions using, essentially, the secular definition the Court created in Rufeisen. See id. at 72 ("[B]y not registering as a Jew anyone born a Jew who is a member of another religion . . they deny the very religious principle according to which they purport to act.").

290. Id. at 64-65 (opinion of Sussman, J.).

291. Id. at 66

292. Id. at 66-67. 
claims, Sussman turned to application of Rufeisen. ${ }^{293}$ Sussman recalled that Rufeisen established that the term "Jew," as a legal term of art, has no settled meaning; Rufeisen was Jewish under the Rabbinical Courts Jurisdiction (Marriage and Divorce) Law of 1953, which was based on halakha, but not under the Law of Return of $1950 .{ }^{294}$ Sussman concludes that given the largely statistical purposes of the Population Registry Law, the malleable and subjective nature of "nationality," and the limited scope of the registration officer's discretion, the officer was required to register the Shalit children in accordance with the application. ${ }^{295}$

Justice Berinson concurred in Sussman's opinion, ${ }^{296}$ but proceeded to explain why his judgment in favor of Shalit was consistent with his views expressed in Rufeisen. ${ }^{297}$ Berinson explained that in Rufeisen, he concluded that the definition of "Jew" for purposes of the Law of Return was not the halakhic definition, but instead rested on popular understanding. ${ }^{298}$ Applying the same principle here, Berinson concluded that "[t]he term 'nation' is to be interpreted according to the popular notion of our place and times." 299 Berinson found it inconceivable that the children of an officer of the Israeli Defense Forces, raised in Israel, and whose mother, while not Jewish, comes from Zionist stock and has "bound her fate with that of the people of the State of Israel," would not be recognized as of Jewish nationality while the "head of the terrorists in East Jerusalem, born of a Jewish woman and a Moslem, who has striven to destroy and annihilate the State of Israel" would be "considered a son of the covenant." ${ }^{300}$

The bulk of Justice Witkon's opinion was spent refuting Justice Landau's contention that the non-Jewishness of Shalit's children was evident on the face of the application, and explaining that the subjective notion of Jewish nationality divorced from halakhic standards was a "legitimate and serious" one. ${ }^{301}$

Justice Cohn, like the other judges in the majority, concluded that the Jewishness of the Shalit children did not present itself for consideration, and that the question was limited to the authority of the registration officer applying the Minister of the Interior's directives. ${ }^{302}$ " $[\mathrm{I}] \mathrm{t}$ is immaterial whether by virtue of instructions or directives he received from the Minister of the Interior, or out of his abundant knowledge of the law or his

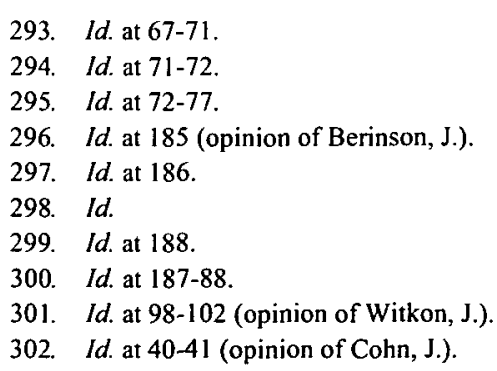


erudition in the Talmud and the Poskim, the registration officer knows (or thinks he knows) with certainty what is or is not the 'nationality' of the person concerned." ${ }^{303}$ Cohn, in accordance with views on subjective identity he expressed in Rufeisen, held that "the notification of the Jewish 'nationality' of the petitioners' children was given bona fide since the petitioners believe with perfect faith that their children's nationality is Jewish, and the contrary directives of the Minister of the Interior certainly cannot bind them." 304

Justice Manny simply concurred with both Sussman and Cohn. ${ }^{305}$

President of the Supreme Court Agranat, dissenting, concurred in large part with Justice Landau. ${ }^{306}$ The President rejected the subjective approach to nationality championed by Cohn, suggesting that this was perhaps even required by Rufeisen (although he did not address what roles Rufeisen's conversion away from Judaism and the fact that it was to another religion, and Christianity specifically, nor the difference between the terms "nationality" in the Population Registry Law and "Jew" in the Law of Return) ${ }^{307}$ Agranat discussed at length the reasons why, in his view, it was not such a simple matter to disassociate religion from nationality, and why Jewish religious law was still a relevant criterion in determining Jewish nationality even for a secular law. ${ }^{308} \mathrm{He}$ suggests that the contrary view "had its source in the school of liberalism and individualism which teaches that religious faith is a matter of conscience falling in the individual's private domain." ${ }^{309}$ After reviewing some of the arguments on both sides, ${ }^{310}$ Agranat concluded that the issue presented depends so heavily on ideological views that judicial resolution of the case would essentially amount to rule by caprice. ${ }^{311}$ Accordingly, Agranat would have let stand the Minister's decision, owing to its lack of amenability to judicial review.

Deputy President of the Supreme Court Silberg explained at the outset that " $[t]$ he problem in all its magnitude and gravity is the substance of the concept 'Jew': can a person belong to the Jewish people without being at the very same time an adherent of the Jewish religion?"312 Silberg contended that the secular definition of "Jew" elucidated in Rufeisen was inapplicable because in Rufeisen, the secular usage was what the Knesset was assumed to have intended. Here, the issue was "nationality," and so he suggested that if there was no definition of "Jew" in general usage

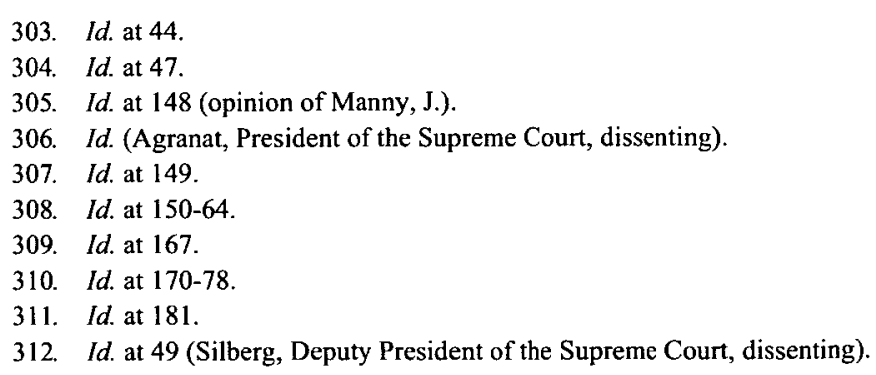


other than that of halakha, then the halakhic definition would be applied notwithstanding the similarly secular nature of the Population Registry Law. ${ }^{313}$ Silberg then proceeded to consider what test should be applied to determine nationality. He concluded that there existed no Israeli nation, only an Israeli state and a much larger Jewish nation. ${ }^{314}$ Suggesting that the abandonment of religious principles would spell the end of the Jewish people, he reached the conclusion that the Jewish nation determined its membership according to religious precepts. ${ }^{315}$

After reprising the basic facts, ${ }^{316}$ Justice Landau noted that Shalit made two arguments: (1) that the registration must be made by the registration officer upon the notification provided, and the registration officer is not empowered to alter that notification; and (2) that even if the registration officer had the power to amend the notification, Shalit's notification to the registration officer that his children were of Jewish nationality was accurate ${ }^{317}$ This case, therefore, squarely presented the question whether in the State of Israel it was possible to be Jewish by nationality (in the ethnic sense as opposed to citizenship), while not being a member of the Jewish people as a religious matter. ${ }^{318}$

Landau thought that Rufeisen could not answer the matter. In Rufeisen, the Court had no trouble concluding that popular sentiment would exclude a Jew by descent who had converted to Christianity from registering as a Jew. But no similar consensus view of "the man on the street" existed with respect to the status of children of mixed marriages where the mother was not Jewish, yet the father was, and the children acculturated Israelis. ${ }^{319}$ Landau, like several of the other judges, concluded that there was little the Court could do to resolve an ideological dispute that turns a "court of law into a court of judges." ${ }^{320}$ Consonant with the views of Agranat on matters ideological, Landau concluded that "the decision must rest with the Knesset which represents the people and, so long as the Knesset has not decided otherwise, with the Government which is entrusted with matters of policy and depends upon the confidence of the Knesset." ${ }^{\prime 321}$

Justice Kister delivered a lengthy opinion ranging from the meaning of "nationality" in the context of political theory, ${ }^{322}$ to the treatment of mixed marriages in Jewish law, ${ }^{323}$ to psychological studies on maternal

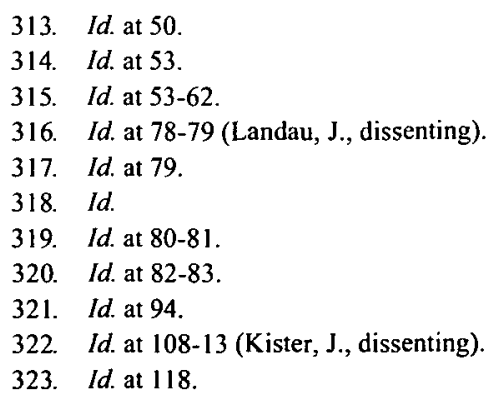


attachment of children. ${ }^{324} \mathrm{He}$ canvassed the dilemma of European Jews during the emancipation and the desire on the part of the Reform movement to reduce Jewish life to religion (in order to make room for an adopted nationality and full political rights). ${ }^{325}$ Kister concluded that the views of the scholars consulted that led to the new directives were a sufficient ground to defer to the government, and that in any event the idea that nationality (as ethnicity) could be acquired simply by "feeling" was incredulous. ${ }^{326}$

\section{Amendment No. 2}

Although Rufeisen and Shalit may appear somewhat contradictory, at least insofar as they reach different results (Shalit winning and Rufeisen losing their respective claims to Jewish status), on closer inspection, the cases reveal a consistent adherence to what the Court considers a "secular" definition of Israeli nationality. ${ }^{327}$ In effect, the Court determined that religion and nationality were separable, and that based on prevailing norms, (1) halakhic non-Jews may be considered Jews for purposes of registration (as in Shalit), and (2) halakhic Jews may be considered nonJews for purposes of the Law of Return (as in Rufeisen). Leaving aside for the moment the difference between registration, which carries no substantive rights, and the Law of Return, which carries immediate and automatic citizenship, the two decisions reflect, sometimes at pains, that the religious view of who is a Jew matters very little apart from questions reserved to the rabbinical courts. This did not sit well with everyone. Despite the fact that "[o]f the five majority justices, only one, Justice Berinson, stated clearly that the Shalit children were Jewish in the secular sense evolved in the Brother Daniel case," ${ }^{\prime 32}$ and "only three out of the nine judges actually delivered any opinion on the controversial question," 329 the Shalit decision was venomously attacked by the Chief Rabbi, the Minister of Religious Affairs, and the Rabbinate's chief executive. ${ }^{330}$

As a result of the public rancor, "[t]he inevitable governmental crisis in the wake of the Shalit case was not long in coming, and in response to the strong protests against the decision made by the religious parties, the Law of Return was amended." 331 Indeed, "[e]ven before anyone had time to

324. Id. at 121 .

325. Id. at 129-31.

326. Id. at $143-45$.

327. Stroman, supra note 79 , at 1547.

328. Rubenstein, supra note 131 , at 89.

329. Id. at 90 .

330. LESLIE, supra note 190, at 42; ABRAMOV, supra note 13, at 303.

331. Sinclair, supra note 12 , at 8 . See also Sapir, supra note 273 , at 1243 (noting that the Shalit decision "triggered a public storm and a threat on the National Religious Party's part to bolt the 
read the lengthy judgment ... the religious parties lashed out against the majority with a ferocity unparalleled in Israel's history of respect for the judiciary." 332 "[U]nder threat by the Orthodox to bring down the government, the Knesset passed legislation directly addressing the Court's decision." ${ }^{.333}$ Out of necessity, the process was rapid. "[T]he new Law was hastily prepared by the Minister of Justice and approved by the Cabinet, presented to the Knesset, discussed, adopted and promulgated: the entire legislative process was completed within a few weeks." 334 The Shalit decision had been handed down on January 23, 1970. By March 16, 1970, the Amendment had been adopted. ${ }^{335}$

The Amendment rejected the Supreme Court's secular position on the severability of religion and nationality. ${ }^{336}$ "It amended the Law of Return by defining as a Jew 'a person who was born of a Jewish mother or has become converted to Judaism and who is not a member of another religion." "337 The Amendment also extended the right of return to a Jew's spouse, children, grandchildren, and the spouses of children and grandchildren, regardless of whether they were Jewish (unless they had previously been Jewish and converted to another religion). ${ }^{338}$ Thus, the Amendment, "[t]hough basically following the religious concept... constitutes a typical compromise between the two ideologies by granting

coalition, a move that would have precipitated the government's downfall."); Edelman, supra note 26, at 218 ("The Shalit decision created a political maelstrom and propelled a most reluctant Knesset to act."); Shava, supra note 14, at 146 ("The judgment in Shalit's case . . . created a public storm and the threat of a governmental crisis due to the dissatisfaction of the National Religious Party."); Klein, supra note 115, at $60 \mathrm{n} .23$ ("The amendments were spurred by the Supreme Court's Shalit decision"); Ginossar, supra note 115 at 264 ("[F]ar from settling the issue, [the Shalit decision] exacerbated it further, even threatening the stability of the Coalition Government."); KRAINES, supra note 130, at 54 ("The Shalit decision stirred the public for days."); Rubenstein, supra note 131, at 89 (noting "a loud and heated debate swept the whole country," "[t]wo religious [government] ministers spoke out against the decision," and "[t]he Rabbinate issued a proclamation stating that any enforcement of the Court's ruling would be contrary to Holy Writ and ordered the Minister of Interior not to obey the Court's decision").

332. Rubenstein, supra note 131, at 89; see also ABRAMOV, supra note 13, at 303.

333. JACOBSON, supra note 78, at 70. See also KRAINES, supra note 130, at 54 ("On January 25 , 1970, the National Religious Party announced that it would resign from the Government Coalition unless the Knesset passed legislation reversing the Court's decision."). In fact, the legislation amending the Law of Return did not address the Court's decision at all. "The Law of Return was not invoked as all the Shalits were Israeli citizens-Anne Shalit by naturalization, the father and children by birth." Rubenstein, supra note 131 at 85 . But see Shalit, supra note 283, at 103, 145 (Kister, J., dissenting) (suggesting that Anne Shalit had not been naturalized).

334. Ginossar, supra note 115, at 264. See also KRAINES, supra note 130, at 54 ("Four days later the Cabinet voted to recommend to the Knesset the legislation demanded by the National Religious Party."); Rubenstein, supra note 131, at 90 ("A week later, the two Shapiros-the Minister of Justice and Minister of Interior-came out with a proposed package deal.").

335. Ginossar, supra note 115 , at 264 n.3.

336. Stroman, supra note 79 , at $1547 \mathrm{n} .15$ (quoting JACOBSON, supra note 78, at 71).

337. JACOBSON, supra note 78, at 70; Law of Return (Amendment No. 2), 5730-1970, 24 LSI 28 (1969-1970) (Isr.). The Population Registry Law was simultaneously amended to preclude registration as a Jew of anyone failing the test laid down for the Law of Return. JACOBSON, supra note 78, at 70; see also Shava, supra note 14, at 146-47; Klein, supra note 115 , at 58-59.

338. Ginossar, supra note 115 , at $266 \&$ n. 10. 
equal rights under the Law of Return to persons who are formally not Jews."339

\section{Beresford}

The final act in the Supreme Court's drama concerns Gary and Shirley Beresford, a Messianic Jewish couple who sought to emigrate to Israel from their home in South Africa. ${ }^{340}$ Beresford is notable because unlike Rufeisen, there was no formal act of affiliation (as with Rufeisen's baptism and subsequent holy orders) and unlike Shalit, there was no absence of some outward manifestation of affiliation (as with Anne Shalit's decision not to convert). Instead, Beresford concerns solely individual beliefs and the result that particular beliefs may have on religious status under civil law. Where Brother Daniel was deemed no longer Jewish because he "linked his destiny to other forces whose precepts he honours in both thought and observance,"341 Beresford took this one step further by making maintenance of Jewish status turn exclusively on thought. The case is also notable insofar as two Justices, applying two very different modes of analysis, come to the same result. At first, this may seem innocuous. But, again, closer inspection reveals that both rely on some of the same suppositions, and there is good reason to believe that suppositions, which frame both analyses, have a significant influence on the result the Court reaches.

Gary Lee Beresford and Shirley Beresford sought oleh's visas to immigrate to Israel under the Law of Return, either as Jews themselves or, under the newly enacted category, as children of Jews. ${ }^{342}$ That both of them were born Jews was not in dispute. ${ }^{343}$ With respect to practice, the Beresfords observed the Sabbath and Jewish dietary laws, were Zionists, and held strong emotional ties with the people, state, and land of Israel. ${ }^{344}$ But the couple also belonged to the "Jews for Jesus" movement. Although

339. Englard, supra note 7, at 194-95. At the time, Israel was preparing for the possibility of massive immigration from the Soviet Union due to the Jewish "national awakening" that country had recently experienced. Weiss, supra note 115, at 94. Many in Israel understood that given the realities of life in the U.S.S.R., they could expect a significant number of Jews with non-Jewish spouses, and there was a call from some quarters to ease the process of immigration for these couples. Id. At the same time as the National Religious Party had acquiesced to broadening the Law of Return to include non-Jewish family members, there was significant pressure to define who was a Jew for Law of Return and registration purposes along religious lines. $I d$.

340. HCJ 265/87 Beresford v. Minister of the Interior 43(4) PD 793 [1987] (Isr.), translated in JEWISH LAW ASSOCIATION StUdies XI: LAW, JUdiCIAL POLICY, aND JEWISH IDENTITY IN THE STATE OF ISRAEL 27-63 (Daniel B. Sinclair ed., 2000) [hereinafter Beresford].

341. Rufeisen, supra note 196, at 23 (opinion of Landau, J.) (emphasis added).

342. Id. at 28. For a more colorful, if unflaggingly sympathetic, background to the Beresfords' case, see LINDA ALEXANDER, The UNPRomised LAND: THE STRUgGLE OF MESSIANIC Jews GaRy \& SHIRLEY BERESFORD (1994).

343. Beresford, supra note 340 , at 28 .

344. Id. 
not Christians--neither had ever been baptized—the Beresfords "came to believe that there is no contradiction between the Jewish faith and the belief in Jesus as the Messiah; this belief, according to their view, is an inseparable part of a clearly Jewish religious movement, which characterized a legitimate stream of Judaism in the Second Temple period" and which they contended was "a legitimate stream of Judaism today." 345

The question before the Court was whether this belief alone, in the absence of baptism and affiliation with any Christian church, rendered the Beresfords "members of another religion" such that they had extinguished their rights, as Jews, to make aliyah under the Law of Return. Justice Elon stressed that formal admission to another religion under its own terms is not required for purposes of the Law of Return (though it would be with respect to matters of personal status adjudicated by the religious courts). ${ }^{346}$ Instead, with respect to the Law of Return, "all that we need ask of the other religion is whether such beliefs are amongst the principles which express the substance and the character of that religion. ${ }^{347}$ Notably, Elon held that what counts is not ceremonial admission, but "theological criteria, i.e. what are the central doctrinal or theological principles through which that other religion finds expression." ${ }^{\prime 38}$ Applying this test, Elon concluded that "the most important thing-even more important than baptism - . . in Christianity - is the belief in the Divinity of Jesus." 349

Elon continued by refuting the Beresfords' claim that Jews for Jesus should be counted among the various branches of Judaism because "[i]n the entire world of Jews and Judaism, in all its movements and divisions, there is not a single community which believes in the divinity of a human being in the incarnation of God, and in a Messiah that has already arrived." 350 Elon held that "Notwithstanding any historical claim that Messianic Jews were once fully accepted as members of the Jewish religion, the situation has changed irreversibly and no person believing in Jesus can claim today to be a Jew under this objective definition." 351 Breaking somewhat with past cases that went to lengths to distance the Court from application of halakha, Elon also turned to several religious

\footnotetext{
345. Id. at $28-29$.

346. Id. at $29-30$.

347. Id. at 30 .

348. Id. at 30 .

349. Id. at 30
}

350. Id. at 32. Of course, this reasoning is deeply flawed; it defines-out Messianic Jews. Any denomination could be similarly excluded by essentializing a particular characteristic or lack of a particular characteristic. For example, if one wanted to define Judaism in theological terms, one could create a definition that "... there is not a single community that does not profess a belief in a supernatural God." Such a definition would exclude Humanistic Judaism. Other examples could be drawn up along similar lines, simply by identifying a particular characteristic and declaring it to be either essential or disqualifying.

351. Sinclair, supra note 12 , at 9 . 
authorities to conclude that even under religious law, an apostate is considered a Jew only for purposes of marriage and divorce. ${ }^{352}$

Justice Barak agreed that the petition must be dismissed, but on rather different grounds. He reasoned that the definition of Judaism for the Law of Return is a dynamic, secular, liberal one, established on the basis of public opinion at any given time. ${ }^{353} \mathrm{He}$ noted that the question before the Court was only the meaning of the phrase "and is not a member of another religion." 354 Barak rejected an earlier approach that assessed whether an individual is a member of another religion by reference to the position of the other religion, because it is "incompatible with the aim underlying the definition of 'Jew' in the Law of Return" which was "intended to establish the identities of those who are entitled to immigration to Israel" and therefore Jewishness cannot be made contingent upon the particularities of a non-Jewish community. ${ }^{355}$ Secondly, applying another religion's membership criteria, although it serves the purpose of permitting relative autonomy of religious groups to direct their own affairs in the matters that have been delegated to them, does not serve any parallel purpose in the context of the Law of Return. ${ }^{356}$ Barak rejects determining who is a member of another religion according to any religious law, including Jewish law, not least because the Amendment was generally thought inconsistent with halakha. ${ }^{357}$ He concedes that the Law of Return is animated by Jewish religious conceptions of Jewry as a body corporate, but concludes that this cannot mean that the Jewish religious conception of "another religion" is what the Knesset intended to adopt. ${ }^{358}$

Instead, Barak held that it must be understood in the context of secular Israeli law. ${ }^{359} \mathrm{He}$ explained that "[t]he expression "is not a member of another religion' is like any other expression in the Law of Return, which must be accorded a secular interpretation. ${ }^{360}$ Relying on the opinions of Justices Silberg, Cohn, Landau, and Berinson in Rufeisen, he noted that the interpretation that governs is the common understanding. ${ }^{361}$ This understanding, he continued, "undoubtedly contains religious elements, for these elements currently constitute a component in the identity of the Jewish people." ${ }^{362}$ But ultimately, it is a criterion of "national-secular and

\footnotetext{
352. Beresford, supra note 340 , at 32-35.

353. Sinclair, supra note 12 , at 9.

354. Beresford, supra note 340 , at 46.

355. Id. at 47.

356. Id. at $48-49$.

357. Id. at $49-51$.

358. Id. at $51-52$.

359. Id. at 53 .

360. Id.

361. Id.

362. Id. at 55 .
} 
not religious significance." 363

Barak concluded that the national-secular definition of the Jewish people excluded those who have a religion other than Judaism that is "their effective religion" to which they "see themselves connected in their every-day lives." ${ }^{64}$ Notably, he explained, "it is essential that this effective connection be incompatible with the secular conception of a person being a Jew," and offered Brother Daniel as a prime example. ${ }^{365}$ "A person who was born of a Jewish mother but has become a Christian priest is 'a member of another religion' since, according to our secular approach, he has stopped being a Jew." 366

Applying this national-secular concept of "Jew" to the case at hand, Barak noted that the Beresfords were not part of the Jewish community in Johannesburg and that they believed in Jesus as the son of God, the Messiah, and the King of the Jews. He also noted, however, that they do not believe in the doctrine of the Trinity and have not been baptized, and that they have a profound connection with the Jewish people. ${ }^{367}$ Conceding that the followers of Jesus in the first century may have seen no contradiction in that pursuit with membership in the Jewish community, Barak concluded that the Jew "from the marketplace" today would take the Beresfords as members of another religion because "it is not possible to skip two thousand years of history as if nothing happened."368 "According to the secular criterion, the other religion-the one to which the Petitioners belong-is Christianity," even if Christians would not view things that way according to Christian doctrine. ${ }^{369}$ The controlling factor is the current secular conception of what it means to be a member of another religion, not whether the petitioners are apostates under Jewish law, or whether they have been formally accepted into another religion according to the norms of the other religion. ${ }^{370}$ Justice Halima concurred in the result without opinion. ${ }^{371}$

\section{B. The Court's Conclusions}

Rufeisen, Shalit, and Beresford raise a number of intriguing points concerning how the Supreme Court of Israel understands what it means as a legal matter to be a Jew and, in turn, what constitutes a "religion" and a

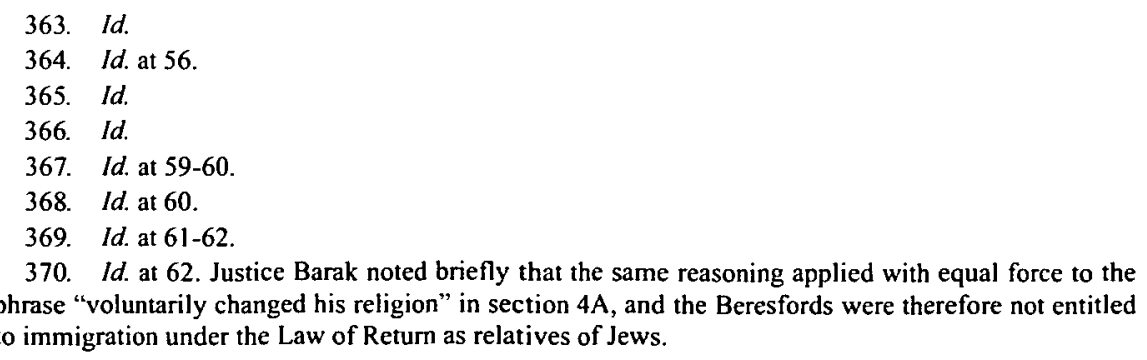

371. Id. at 63 . 
"nationality." First, a strong majority of the Court in Rufeisen rejected the notion that who is a Jew for purposes of the Law of Return should be determined according to halakha. ${ }^{372}$ Instead, Rufeisen referred to the popular understanding of religion to make that determination. ${ }^{373}$ Popular understanding, in turn, "treated conversion as decisive." 374 Rufeisen had placed himself outside of the Jewish community "in both thought and observance." ${ }^{375}$ Shalit held that nationality is subjective (or at least mostly subjective) but to reach that conclusion had to assume that religion and nationality are separable categories. ${ }^{376}$ And finally Beresford took Rufeisen one step further, holding that religion is primarily a matter of belief and closing the door on the possibility raised in Rufeisen that formal affiliation is necessary. ${ }^{377}$ In Rufeisen, Berinson suggested that had Rufeisen become a Buddhist, rather than a Christian monk, he would not have extinguished his right of return. ${ }^{378}$ After Beresford, that possibility appears to be foreclosed.

In short, for the Supreme Court of Israel, religion is 1) something separable from nationality and 2) primarily a matter of belief. These conclusions, although not inevitable, were also not unprecedented in Israeli history. For example, a minister of the Jewish Agency said that not joining another religion is a requirement of Jewish status for aliyah. ${ }^{379}$ This conclusion may have been based on a statement Herzl made that a Jew who converted to another religion was not a Jew and was not entitled to membership in the Zionist Organization. ${ }^{380}$

In reaching these conclusions, the Court understood itself to be applying an "ordinary" or "secular" understanding of "religion" and "nationality." 381 Oswald Rufeisen himself admitted, "had my position been accepted this would have created a revolution in conventional concepts." ${ }^{382}$ But how did these concepts come to be considered

372. Sinclair, supra note 12 , at 5 .

373. Slovenko, supra note 118, at 15; LESLIE, supra note 190, at 39; JACOBSON, supra note 78, at 65 (noting that for the majority, "the secular meaning of the term 'Jew' in the Law of Return is to be derived from the common understanding of the 'ordinary simple Jew.'"); Green, supra note 200, at 191.

374. Rubenstein, supra note 131 , at 88 .

375. See Rufeisen, supra note 196, at 23 (opinion of Landau, J.).

376. See supra notes $277,287-88,295,300$, and accompanying text.

377. See supra note $367-70$ and accompanying text. See also Rufeisen, supra note 196, at 23 (opinion of Landau, J.) (noting importance of both "thought" and "observance").

378. Rufeisen, supra note 196, at 31 (opinion of Berinson, J.).

379. TEC, supra note 160 , at 226.

380. Rubenstein, supra note 9 , at 109.

381. Slovenko, supra note 118, at 16-17 ("[T]he Court in the Brother Daniel case looked to the ordinary meaning of the term 'Jews.' Justice Silberg made reference to the 'ordinary every meaning' of the word as used by Jews; Justice Landau spoke of the 'instinct of the overwhelming majority of Jews today' ... and Justice Berenson, of the 'common meaning of the word' and of the 'popular understanding."'); Galanter, supra note 157, at 11 (same).

382. TEC, supra note 160 , at 231. 
"ordinary" and "conventional"- so ubiquitous and fundamental as to be unworthy of critical inquiry, and so widely accepted as to be presumptively neutral?

The answer appears to be two-fold. First, "religion" is generally understood to mean something chiefly concerned with beliefs because Christianity is chiefly concerned with beliefs. "Religion" historically connoted those non-Western modes of behavior, rituals, institutions, etc. that had at least rough parallels in Christianity. "Religion" is, at its core, a Christian category. But as the centrality of religion generally and Christianity specifically declined in the West, the idea of religion as an isolable component of the human experience lost the connection to its Christian origins. Eventually, the Christian idea of "religion" was adopted by non-Christians. Religion was reified as a legal construct in constitutions and laws guaranteeing "freedom of religion." And as religion became a universal concept, there seemed little reason to question its provenance or its neutrality as a category.

\section{A CHRISTIAN CONCEPTION}

The approach the Supreme Court of Israel has taken to defining who is a Jew under civil law is not secular, but is instead derived from the history of Christian hegemony in the West. ${ }^{383}$ It is not a neutral definition, but rather a sacrifice-intentional or not-of a Jewish corporate selfconception at the altar of Christian universalism.

\section{A. A "Rather Odd Modern Concept" $" 384$}

In colloquial speech, "religion" is "one of the simplest, most obvious and minimal terminological statements" one can make. ${ }^{385}$ As understood by the Court, the concept is essentially "transhistorical and transcultural," 386 i.e., unhistoricized, essentialized, and tacitly presumed immune to or inherently resistant to critical analysis." 387 Even today, the category "world religions" belies a pervasive, unexamined, and "rather monumental assumption... that religion is a universal, or at least ubiquitous phenomenon to be found anywhere in the world at any time in history. $" 388$

But despite its ubiquity, "[t]he modern concept of religion ... is not a

383. See Didi Herman, AN UNFortunate CoIncidence: Jews, Jewishness, \& ENGlish Law 16 (2011) ("[S]ecularism becomes a term that facilitates judicial Christian thinking").

384. BATNITSKY, supra note 22, at 13, 190.

385. Dan, supra note 1 , at $\mathrm{XxV}$.

386. Talal Asad, Genealogies of Religion: Discipline and Reasons of Power in CHRISTIANITY AND ISLAM 28 (1993).

387. TOMOKo MASUZAWA, THE INVENTION OF WORLD RELIGIONS 1-2 (2005).

388. Id. at 1 . 
neutral or timeless category but instead a modern, European creation, and a Protestant one at that." ${ }^{.389}$ Leora Batnitzky explains "this Protestant notion simply as the view that religion denotes a sphere of life separate and distinct from all others, and that this sphere is largely private and not public, voluntary and not compulsory." 390 An understanding of religion that gives primacy to propositional belief (which occupies the private, voluntary sphere) has been called "a modern, privatized Christian one because and to the extent that it emphasizes the priority of belief as a state of mind rather than as constituting activity in the world." common understanding of "religion," as primarily a matter of voluntary, internal, propositional belief is neither neutral nor secular. ${ }^{392}$ It assumes and is built on a Christian normativity.

The extent to which "religion" is a product of post-Enlightenment Protestantism or of the early Christian period is not well understood. ${ }^{393}$ But the idea of religion, as it "is generally recognized, derive[s] from Western cultural traditions and experiences. ${ }^{, 394}$ Ruth Langer and Joseph Dan agree "that the very concepts of religion and theology as the academy understands them today are Christian concepts, derived from Christianity's early accommodations with Greco-Roman culture, resulting

389. BATNITSKY, supra note 22, at 1, 13, 190; see also Linda Woodhead, Five Concepts of Religion, 21 INT"L REv. SOC--REVUE INTERNATIONALE DE SOCIOLOGIE 121, 123 (2011) ("[T]he conception of religion as a matter of belief is a distinctly modern one, with a bias toward modern Christian, especially Protestant, forms of religion."); Hent de Vries, Introduction: Why Still "Religion"?, in RELIGION: BEYOND A CONCEPT 1, 4 (Hent de Vries ed., 2008) (Religion points to "many concepts, in any event, the ones we have come to associate with it too quickly, influenced by a Western and especially Protestant idiom."); James Boyd White, Talking About Religion in the Language of the Law, in JAMES BOYD WHITE, FROM EXPECTATION TO EXPERIENCE: ESSAYS ON LAW AND LEGAL EDUCATION 124, 131 (1999) ("Here is the image of religion (I think deeply Protestant in nature) to which I have been repeatedly exposed. Religion at heart consists in something called 'belief'; this belief is arrived at by an individual, in whatever way seems best to him or her; the object of this belief is a set of propositions, usually about a Supreme Being, sometimes about a set of beings superior to the human; this being (or beings) issues commands to human beings, who are threatened with punishment, often eternal punishment, if they fail to comply; and the life of religion consists in large part of obedience to these commands.").

390. BATNITSKY, supra note 22, at 13.

391. Charles Taylor, The Future of the Religious Past, in RELIGION: BEYOND A CONCEPT 178, 178-79 (Hent de Vries ed., 2008) ("One of the main vectors over the last six or seven centuries in this civilization has been a steadily increasing emphasis on a religion of personal commitment and devotion, over against forms centered on collective ritual."); ASAD, supra note 386, at 47.

392. See generally Petty, supra note 6, at 135-42 (discussing origin and development of the concept of religion).

393. Daniel Boyarin, Border Lines: The Partition of Judaeo-Christianity 11 (2004).

394. Benson Saler, Religio and the Definition of Religion, 2 CUltural ANTHROPOLOGY, 395, 395 (1987). See also Jan G. Platvoet, Contexts, Concepts and Contests: Toward a Pragmatics of Defining Religion, in THE PRAgmatics OF DEFInING Religion: ConTEXTS, CONCEPTS AND CONTESTS 463, 463-64 (Jan G. Platvoet \& Arie L. Molendijk eds., 1999) ("[T]he modern terms 'religion' and 'religions' are diffuse and untidy prototypical concepts of recent Western origin."); Russell T. McCutcheon, The Category "Religion" in Recent Publications: A Critical Survey, 42 NUMEN 284, 285-86 (1995) (citing Tim Murphy, Wesen under Erscheiung in the History of the Study of Religion: A Post-Structuralist Perspective, 6 METHOD \& THEORY IN THE STUDY OF RELIGIONS 119 , 119-46 (1994) ("universalized categories as 'religion' - defined as essence or manifestation, are part of the baggage of Occidental Humanism.")). 
in a clear differentiation between the realms of church and state and between theology and philosophy." 395 In the Roman context, "religio" denoted that aspect of human life which is dedicated to the worship of the gods; a corner of the week's activities and a few days of festivals." 396

The Protestant Reformation redefined religio to correspond to individual beliefs. ${ }^{397}$ In contrast to their perception of Roman Catholic practice wherein the individual's relationship with God was mediated by priests performing sacraments and rites, Protestants sought a more direct relationship between the individual and God. ${ }^{398}$ Thus, many of the "position[s] and functions formerly controlled by the church came to be transferred to the individual and his or her conscience." 399

During the Enlightenment the construct of "religion" - as a category broader than Christianity alone - was "forged into a recognizably modern form," $" 400$ which "drew heavily upon prior Christian understandings."401 Indeed, it was not until Enlightenment that the term "Christianity" becomes standard and increasingly comes to refer to "a system of beliefs." 402 And "[b]y the eighteenth century, religion did not refer mainly

395. Langer, supra note 141 , at 257 ; see also Dan, supra note 1 , at xxvi ("Christianity did describe itself as a religion. It accepted this term from the Hellenistic world, especially from Roman ways of worship.").

396. Dan, supra note 1, at xxvi; see also BATNITSKY, supra note 22, at 6 ("The modern concept of religion also indicates that religion is one particular dimension of life among other particular and separate dimensions, such as politics, morality, science, or economics.").

397. See Robert A. Yelle, Moses' Veil: Secularization as a Christian Myth, in AFTER SECULAR LAW 23, 34 (Winnifred Fallers Sullivan et al. eds., 2011) ("The triumph of an antinomian concept of religion ... was . . largely a product of the Reformation."); Woodhead, supra note 389 , at 123 ("The 'confessionalization' of religion in the post-Reformation period tended to define and distinguish different forms of religion (particularly Christianity) in terms of distinctive 'confessions' of faith."); Carolyn Evans, Introduction, in LAW AND RELIGION IN THEORETICAL AND HISTORICAL CONTEXT 1, 8 (Peter Cane et al. eds., 2008) ("This is a particularly post-Reformation Western view of religion that gives primacy to the internal, intellectual aspects of religion over other viewpoints"); Taylor, supra note 391 , at 179 ("The point of declaring that salvation comes through faith was radically to devalue ritual and external practice in favor of inward adherence."); de Vries, supra note 389, at 5 (discussing "... the modern definition of the concept, which has so often, and all too hastily, identified 'religion' with a 'set of beliefs."').

398. JAMES TURNER, Without God, Without CREED: The ORIGINS OF UNBELIEF IN AMERICA 23-24 (1985).

399. Steven D. Smith, Discourse in the Dusk: The Twilight of Religious Freedom?, 122 HARV. L. REV. 1869, 1877 (2009); see also Molendijk, supra note 5, at 5 ('Does the notion [of 'religion'] not preserve a one-sided-Schleiermachian-focus on the inner religious sentiment as well? The alleged eurocentricity, especially, makes Western scholars feel uneasy.").

400. Saler, supra note 394, at 395. See also PETER HARRISON, 'RELIGION' AND THE RELIGIONS IN THE ENGLISH ENLIGHTENMENT 1 (1990) ("The concepts 'religion' and 'the religions' ... emerged quite late in Western thought, during the Enlightenment."); ASAD, supra note 386, at 45 (noting the modern view of religion as that which consists of "a positive attitude toward the problem of disorder, of affirming simply that in some sense or other the world as a whole is explicable, justifiable, bearable ... is a product of the only legitimate space allowed to Christianity by post-Enlightenment society, the right to individual belief').

401. Michael L. Satlow, Defining Judaism: Accounting for Religions in the Study of Religion, 74 J. AM. ACAD. RELIGION 837, 841 (2006).

402. Wilfred CANTWEll SMITH, THE MEANING AND END Of RELIGION 70-71 (1964). 
to ritual practice or performance, but instead to personal belief or faith." The equation of religion with faith, therefore, "involves the reproduction of a Christian worldview." 404 Among scholars of religion, "[i]t has become a truism that religion in its modern sense is an invention of Christians." ${ }^{405}$ As James Boyd White sardonically noted, "religious belief" means the affirmation of certain propositions. What else could it be?"406 Certainly for the Supreme Court of Israel, the affirmation of Christian articles of faith has often been determinative.

\section{B. Christianity is a Religion. Judaism "Refuses to be One." 407}

The tension between Judaism and the common notion of religion is "one of the most vexed problems of modernity." ${ }^{408}$ At least until very recent times, Judaism did not fit with the internal, private, voluntary Protestant conception of religion. ${ }^{409}$ "Adherence to religious law, which is at least partially, if not largely, public in nature, does not seem to fit into the category of faith or belief, which by definition is individual and private." ${ }^{, 410}$ In Judaism, actions matter most. As Moses Mendelssohn explained, "Among all the prescriptions and ordinances of the Mosaic law, there is not a single one which says: You shall believe or not believe. They all say: You shall do or not do."411 As Mendelssohn elaborated, "Jewish religion is not a matter of belief but rather of behavior. As he puts it, 'Judaism knows of no revealed religion in the sense in which Christians. understand the term. The Israelites possess divine legislation-laws, commandments, ordinances, rules of life, instruction in the will of God as to how they should conduct themselves in order to attain temporal and eternal felicity." ${ }^{412}$ Indeed, plurality of belief and of observance have been identifiable features of the Jewish experience since at least the

403. BATNITSKY, supra note 22, at 1 ; see also GAVIN I. LANGMUIR, HISTORY, RELIGION, AND ANTISEMITISM 70 (1990) (By the eighteenth century, after the Roman Catholic monopoly on European Christianity failed, the term "religion" "came to be applied to the beliefs of the competing religious societies into which Europe had been fragmented.").

404. BATNITSKY, supra note 22 , at 1 .

405. Id. at 11 . As early as the 1960 s sociologists began to recognize that the conceptions of religion holding sway in academic studies were heavily influenced by the investigators' own Christian milieu. See Woodhead, supra note 389, at 121 ("Thomas Luckmann (1967) argued that sociological studies of religion hugged the form of churches so closely that they rendered other manifestations of religion "invisible."').

406. White, supra note 389 , at 133.

407. Id. at 8,12 .

408. BATNITSKY, supra note 22, at 13, 190. See also id. at 1 ("From the eighteenth century onward, modern Jewish thinkers have been concerned with the question of whether or not Judaism can fit into a modern, Protestant category of religion.").

409. Victoria S. Harrison, The Pragmatics of Defining Religion in a Multi-Cultural World, 59 INT'L J. PHIL. RELIGION 133, 134 (2006) ("[R]eligion cannot so easily be identified with the affirmation of a given content of belief.") (internal quotation marks omitted).

410. BATNITSKY, supra note 22, at 1.

411. Id. at 27.

412. Id. at 20 . 


\section{destruction of the Second Temple. ${ }^{413}$}

Conversely, "Judaism is not and has not been, since early in the Christian era, a 'religion' in the sense of an orthodoxy whereby heterodox views, even very strange opinions, would make one an outsider." ${ }^{, 414}$ Belief matters little. Indeed, Amos Funkenstein suggests that "no written or oral commandment forbids an orthodox Jew even now to believe in the messianity of Christ." 415 And "[f]or most Jews, religious observance is a means of identifying with the Jewish community, rather than an expression of religious faith." that can be separated from ethnicity, nationality, language, and shared history have felt false." ${ }^{\$ 17}$

Beyond the focus on actions rather than belief, Judaism did not understand itself to be a "religion" in the Greco-Roman sense adopted by Christianity: "a corner of the week's activities and a few days of festivals." 418 Instead, Judaism saw itself "expressing the totality of the meaning and purpose of every single aspect of human activities." $" 419$ As Hirsch explained, "Judaism is not a religion .... Judaism is not a mere adjunct to life: it comprises all of life."

"'Religion' and its cognate terms seem self-evidently meaningful because they are so deeply embedded and widely used in everyday language. But their meaning is loose and largely influenced by traditional-and conflicting-religious preconceptions." ${ }^{" 421}$ For this reason, "[i]f historians categorize Judaism and Christianity as instances of

413. Hayim Lapin, The Origins and Development of the Rabbinic Movement in the Land of Israel, in The Late Roman-RabBinic Period 214 (Steven T. Katz ed., 2006).

414. BOYARIN, supra note 393 , at 13.

415. AMOS FUNKENSTEIN, PERCEPTIONS OF JEWISH HISTORY 170 (1993).

416. Zvi Gitelman, The Decline of the Diaspora Jewish Nation: Boundaries, Content, and Jewish Identity, 2 JEwISH SOC. STUD. 112, 119 (1998) (internal quotation omitted); see also Andrew Buckser, Secularization, Religiosity, and the Anthropology of Jewry, 10 J. MODERN JEWISH STUD. 205, 208 (2011) ("[G]roup identity and membership are intimately linked to religious practice.").

417. BOYARIN, supra note 393, at 8; see also Buckser, supra note 416, at 208 ("In Judaism ... ritual has a religious value of its own, one substantially independent of the particular theological meanings attached to it.").

418. Dan, supra note 1, at xxvi; see also BATNITSKY, supra note 22, at 6 ("The modern concept of religion also indicates that religion is one particular dimension of life among other particular and separate dimensions, such as politics, morality, science, or economics.").

419. Dan, supra note 1 , at xxvi. On the other hand, "in the last two centuries a large segment of the Jewish people moved from one understanding of the meaning of 'religion' to another." Id. at xxviii. And today, virtually "[a]ll contemporary Jewish religious denominations ... [have] adopted the Christian concept of religion as an individual spiritual realm which constitutes a part of human life, besides which other profane aspects of life and culture can co-exist." Id. In fact, Orthodox Judaism may have adopted the Protestant model the most fully. See BATNITSKY, supra note 22, at 43 ("[T] he historical irony is that Hirsch's orthodoxy is not only modern, but rather in a certain sense the most modern of modern Judaisms in molding itself as a religion on the German Protestant model."). See also Woodhead, supra note 389, at 124 (noting that "a 'beliefification' of religion is also evident in other [non-Christian] world religions in modern times").

420. BATNITSKY, supra note 22 , at 41 .

42I. LANGMUIR, supra note 403 , at 6. 
the same kind of basic human activity, as 'religion,' despite the obvious differences in the beliefs and actions of Jews and Christians, they should recognize that they themselves are deciding what they mean by religion." ${ }^{422}$ Daniel Boyarin, for example, suggests that the categorization of Judaism as a religion is wholly artificial when he says "it is not the case that Christianity and Judaism are two separate and different religions, but that they are two different kinds of things altogether." ${ }^{, 23}$

\section{A Supreme Irony?}

At first blush it seems that the Supreme Court of Israel's apparently unwitting importation of Christian norms into Israeli jurisprudence is enormously ironic (particularly given some of the venomous language in Rufeisen and Beresford about how awful Christians have been to Jews over the years). The more the Court attempted to distance itself from halakhic rules in favor of what it understood to be "secular" concepts, the more it stumbled into Christian norms concerning religion and even Judaism. But the Court's apparent lack of interest in critically examining the concepts applied is perhaps not entirely unjustified. In other words, the adoption of Christian norms may have served some useful purpose notwithstanding the Court's lack of critical analysis of the category itself.

\section{Forging an Identity}

"The new Jewish culture which developed in Eretz Israel in the first half of the twentieth century was modern, Western and secular." ${ }^{2424}$ The young state, including the Supreme Court, had a mandate to reflect that culture. Thus, in Rufeisen, all of the Justices expressed a view that halakhic rulings would not control the outcome. ${ }^{425}$ The Court went to pains to show that Israel was not a theocratic state, and that the civil courts would not defer to rabbinic rulings on matters of civil law (even where civil law imported what might be religious concepts or terminology). Israel wanted to show it was modern and enlightened, more European than Levantine, and that meant a civil legal system separate from and superior to religious tribunals.

Beyond this urgency to cabin any potential criticism that Israel would

422. Id. at 46. Even so, this is still how religion is generally understood, even in the academy. See Evans, supra note 397, at 8 (noting that "[f]or most of the authors [in an edited volume], religion is primarily a set of beliefs - beliefs that are capable of being adopted, rejected, modified or refined at the will of the believer"); Woodhead, supra note 389, at 123 ("One of the most popular conceptions of religion today - if one takes as evidence not only academic work but the discourse of politicians, legal professionals, journalists, and everyday talk-is of religion as belief. On this account, being religious has to do with believing certain things, where that amounts to subscribing to certain propositions and accepting certain doctrines.").

423. BOYARIN, supra note 393 , at 13.

424. MAUTNER, supra note 20 , at 29.

425. See JACOBSON, supra note 78 , at 64 . 
become a Jewish theocracy, there was at the same time a struggle to forge a national identity. During the 1950 s,

significant efforts were invested in the creation of national symbols and a national identity: "The creation of Israel and the tripling of its population in three years led state leaders to feel that the country must be completely integrated; that the value-belief systems separating the various camps must be abolished and replaced by a unified symbol system uniting the entire Jewish population in support of the state and its institutions." 426

"This ideology... in many respects... acquired the role of a civil religion for Israel." ${ }^{.427}$ Even apart from matters of security, the Court clearly had more pressing concerns than the historical nuances of widely shared concepts.

\section{The Relationship Between Nation-State and Religion}

Moreover, at the same time that Israel was trying to define itself as a state, it also had the task of defining the state's relationship with religion. This posed a unique challenge. European nations defined religion in Christian terms (and their former colonies had it so defined for them). This meant that in Europe, religion was not just internal, individual, private, voluntary, and separable from other categories of existence (as Christianity is) but also that Christians, as a community, did not constitute a political entity. Indeed, the idea of religion as it is understood in modern states assumes a lack of political control. In the modern state, "citizenship meant the subordination of any communal identity to the state and the relegation of religion to the sphere of private sentiment." ${ }^{\text {"28 }}$ This distribution of power-with the nation-state governing external actions and serving as a locus for communal identity, while religion governs internal beliefs and is primarily concerned with the individual-fits comfortably when the religion in question was Christianity.

For Jews living in Europe, the separation of religion from temporal authority posed a problem because the pre-emancipation Jewish communities were to a significant extent self-governing. They did hold political power over their members, and they claimed primary importance in constituting their members' identities. ${ }^{429}$ "The whole concept of Jewish

426. BARAK-EREZ, supra note 2, at 36 (quoting CHARLES S. LiEBMAN \& ELIEZER DON-YeHHIYA, CIVIL RELIGION IN ISRAEL: TRADITIONAL JUDAISM AND POLITICAL CULTURE IN THE JEWISH STATE 82 (1983)).

427. Id. The Israeli national identity is thus "inspired by religious history but detached from religion as such." Id. at 37. And today, there is "a growing detachment among the Israeli secular public from traditions that had previously also been respected by non-religious Jews, together with a declining willingness to view religious elements of the culture as having national significance." Id. at 3.

428. Id. at 33 .

429. ABRAMOV, supra note 13, at $98-99$ ("The political framework of the corporate medieval 
identity, in its traditional sense, is founded upon the Covenant (Brit) between God and the Jewish people. . . . It is this Covenant which . . . because of its continuity, defines a Jew independently of his own personal belief." $\$ 30$

"[B]efore Jews received the rights of citizenship, Judaism was not a religion, and Jewishness was not a matter of culture or nationality. Rather, Judaism and Jewishness were all of these at once: religion, culture and nationality." ${ }^{431}$ Graetz explained that

Judaism is not a religion of the individual but of the community. That actually means that Judaism, in the strict sense of the word, is not even a religion - if one understands thereby the relationship of a man to his creator and his hopes for earthly existence--but rather a constitution for a body politic. ${ }^{432}$

In order to secure the place of Jews in the modern nation-state, Judaism surrendered much of its political authority. ${ }^{433}$ "Jewish modernity most simply defined represents the dissolution of the political agency of the corporate Jewish community and the concurrent shift of political agency to the individual Jew who also became a citizen of the modern nationstate." ${ }^{\prime 434}$ The emancipation of individuals came at the cost of collective political autonomy. "It "meant that Jews were free as individuals, but that Jewishness and even a full embrace of Judaism could not be freely expressed within German culture. The notions of being German and citizenship in the modern state excluded the possibility of other types of

state allowed for the Jewish enclave to be in the state but not of the state. The disciplined Jewish community lived largely by its own law, which the rabbis, through their interpretations, applied to concrete situations in changing circumstances."); Salo Baron, Ghetto and Emancipation: Shall We Revise the Traditional View?, XIV THE MENORAH J. 515, 519 (1928) ("Like other corporations, the Jewish community enjoyed full internal autonomy... Thus the Jewish community of prerevolutionary days had more competence over its members than the modern Federal, State, and Municipal governments combined.").

430. Rubenstein, supra note 131 , at 85 .

431. BATNITSKY, supra note 22, at 186. See also Rubenstein, supra note 131, at 85 ("Judaism does not conform to the ordinary rules of nations and religions"); BATNITSKY, supra note 22, at 1-2 ("To appreciate the novelty of the idea of Jewish religion, we need to understand a bit about the nature and structure of medieval and early modern Jewish communities. Prior to modernity [emancipation] Judaism was not a religion, and Jewishness was not a matter of culture or nationality. Rather, Judaism and Jewishness were all these at once: religion, culture, and nationality.").

432. BATNITSKY, supra note 22, at 45. See also id. at 46 ("Granting Judaism a political dimension means, as Graetz indicates, that Judaism does not quite fit the category of religion."); Dan, supra note 1, at xxviii ("The use of the term 'religion' in a Jewish context is, therefore, an external imposition rather than an authentic expression of the intrinsic nature of Judaism."). But see BATNITSKY, supra note 22, at 43 (discussing Hirsch's creation of Jewish orthodoxy in the German Protestant model).

433. ABRAMOV, supra note 13, at $98-99$ ("The French Revolution and the Emancipation brought about the disintegration of Jewish autonomous life in Europe."); Baron, supra note 429, at 524 ("When the modern State came into being and set out to destroy the medieval corporations and estates to build a new citizenship, it could no longer suffer the existence of an autonomous Jewish corporation.").

434. BATNITSKY, supra note 22, at 4; see also id. at 92 ("Mendelssohn . . invented the idea that Judaism is a religion in order to make room for the emergence of the modern nation-state."). 
collective belonging." ${ }^{435}$ Thus, the French politician Comte de ClermontTonnerre claimed that "[o]ne must refuse everything to the Jews as a nation, but one must give them everything as individuals; they must become citizens. ${ }^{2436}$

The nascent Israeli state had the arduous task of reconciling a dominant non-Christian religion with its existence as a nation state. Being a modern nation-state required "religion" to occupy a private, internal space subordinate to the state and with little, if any, temporal political power. Anything less would risk charges of theocracy. A move toward an understanding of Judaism as a religion in the sense that religion is understood in Christian states avoided that difficulty.

\section{Zionism as Normalization}

Finally, the influence of Zionism must be considered. If the raison d'etre of Zionism is to normalize the situation of the Jews, ${ }^{437}$ then perhaps it makes sense that Israel should understand religion in Christian terms independently of the state's desire to minimize religious authorities' influence over the affairs of state. Normalization means to be a nation among the other nations of the world, ${ }^{438}$ and if the international community generally views religion in one (Protestant) way, then why not assume that viewpoint if it furthers that goal of Zionism? On the other hand, if the point of Zionism is to allow Jews full political participation with full Jewish experience, it is difficult to see how a full Jewish experience is possible where religion is not understood by the nominally Jewish state on Jewish terms.

\section{RECONCEPTUALIZING SECULARIZATION}

So far, I have suggested that the understanding of "religion" employed by the Supreme Court of Israel is one premised primarily, if not exclusively, on belief, and that this understanding is moored in Christian theology. I have also explained why this might be so, and tentatively explored the extent to which the highest court in the "Jewish state" might have adopted, even if unwittingly, Christian normativity in its conception

435. Id. at 49; see also id. at 111 ("[I]f Judaism is a religion, it is something different in kind from the supreme political authority of the sovereign state."); Baron, supra note 429, at 524 ("Political equality also meant the dissolution of the autonomous communal organization: the Jews were no longer to be a nation within a nation; they were to be thought of and to think of themselves as individuals connected only by ties of creed-Frenchmen, Germans, Englishmen of the Jewish 'Confession."').

436. Id. at 33 .

437. Rubenstein, supra note 131, at 85 ("Zionism sought to solve the Jewish problem by 'normalising' the Jews.").

438. Id. ("In a sense, political Zionism attempted to do on a national basis what Jews sought in vain to do individually, i.e. to be like all the other Goyim."). 
of "religion." In this final part, I will attempt to place these findings in the larger context of the debate over secularization.

\section{A. The Secularization Debate}

Like "religion," the notion of " " $[\mathrm{t}]$ he secular' was, in fact, originally a religious concept, a product of traditional religious epistemological frameworks." $" 439$ The word "finds its original meaning in a Christian context. Saeculum, the ordinary Latin word for century, or age, took on a special meaning as applied to profane time, the time of ordinary historical succession which the human race lives through between the Fall and the Parousia." 440

The noun "secularization" is likewise a Christian and specifically Protestant construction. ${ }^{441}$ This usage originated in France where it signified, in the second half of the sixteenth century (during the Reformation), "the transfer of goods from the possession of the Church into that of the world." $" 442$ It was brought into German no later than 1646, and gained wide acceptance quickly in connection with the closure of monasteries and liquidation of goods of the Roman Catholic Church. ${ }^{443}$

"The notion of secularization has a long history in the social sciences, tracing back at least to Auguste Comte's argument that a rational modern society would render religion obsolete." 444 "Weber and Durkheim both forecast the marginalization of religion in modern societies, and their successors built the decline of religion into their models of social

439. Nomi Stolzenberg, The Profanity of Law, in LAW AND THE SACRED 29, 30 (Austin Sarat et al. eds., 2007).

440. Charles Taylor, Modes of Secularism, in SECULARISM AND ITS CRITICs 31, 31-32 (Rhajeev Bhargava ed., 1998). The Parousia is "the Second Coming of Christ that would precede the Last Judgment." Jakob de Roover, Secular Law and the Realm of False Religion, in AFTER SECULAR LAW 43, 46 (Winnifred Fallers Sullivan et al. eds., 2011).

441. See generally Yelle, supra note 397 ; see also Nomi Maya Stolzenberg, Theses on Secularism, 47 SAN DIEGO L. REV. 1041, 1057 (2010) ("[T] he idea of a realm of the secular, split off from a spiritual realm, was originally a religious idea, derived from the premises of religious-in particular, Christian - theology."); Taylor, supra note 440, at 31 ("'Secular' itself is a Christian term . ..”); Eduardo Peñalver, Note, The Concept of Religion, 107 Y ALE L.J. 791, 813 (1997) ("Even within Christianity, the dualistic connotation of 'religion' as standing in opposition to the 'secular' (that is, nonreligious) is rooted in a very Protestant understanding of a world divided into Luther's Two Kingdoms.").

442. Jan N. Bremmer, Secularization: Notes Toward a Genealogy, in RELIGION: BEYOND A CONCEPT 432, 433 (Hent de Vries ed, 2008) (internal quotation omitted); Kevin M. Schultz, Secularization: A Bibliographic Essay, ThE HedgeHOG ReVIEw, Spring \& Summer 2006, at 170, 172.

443. Bremmer, supra note 442 , at $433-34$. But apparently saecularisatio was not the term used in canon law prior to this date, instead using profanatio or alienatio/alienare to mean transfer to lay persons, and saecularisatio to refer to transfer from religious orders to secular clergy. Veit Bader, Religion and the Myths of Secularization and Separation, RELIGARE WORKING PAPER NO. 8, 2011, at 8 .

444. Buckser, supra note 416, at 206. See also Philip S. Gorski \& Ateş Altınordu, After Secularization?, 34 ANN. REV. SOC. 55, 56 (2008); Jeffrey K. Hadden, Toward Desacralizing Secularization Theory, 65 SOC. FORCES 587, 587, 590-91 (1987). 
modernization." 445 But not until "about 1963, when two Central Europeans, Peter Berger and Thomas Luckmann, started publishing studies regarding secularization, did the term receive more or less its modern meaning." ${ }^{446}$

"The secularization thesis, advocated by seminal social thinkers in the nineteenth and twentieth centuries, asserted that religion would gradually fade in importance and even cease to be significant with the advent of modern society." 447 The traditional formulation of secularization, the phenomenon, holds that " "the political ends of citizens, organizations, and societies themselves are no longer as explicitly religious as they once were or are no longer explicitly religious at all."" 448

Today, "there seems to be a nearly universal consensus that the socalled 'secularization thesis' has failed." 449 The theory, which previously had been closer to a mathematical postulate, ${ }^{450}$ began to deteriorate in response to events such as the Iranian revolution and the rise of the Christian right in the United States. ${ }^{451}$ In short, "[c]ontinued religiousity became a nagging problem. ${ }^{, 452}$ And "... by the 1990s, [when] it became evident that religion just wasn't going away; critiques of secularization

445. Buckser, supra note 416, at 206-07.

446. Id. But see William H. Swatos, Jr. \& Kevin J. Christiano, Secularization Theory: The Course of a Concept, 60 SOC. RELIGION 209, 209-10 (1999) (suggesting the term was coined by Max Weber).

447. Paul Cliteur, The Secular Outlook: In Defense of Moral and Political SECULARISM 1-2 (2010); STEVE BRUCE, SECULARIZATION 1 (2011) ("The secularization paradigm aims to explain one of the greatest changes in social structure and culture: the displacement of religion from the centre of human life."); Swatos \& Christiano, supra note 446, at 214 ("The principle thrust in secularization theory has [been] ... that, in the face of scientific rationality, religion's influence on all aspects of life-from personal habits to social institutions-is in dramatic decline."). The secularization debate, as a (postulated) sociological phenomenon is distinct from secularism as a normative value in ethics, politics, morals, etc. See CLITEUR, supra, at 3.

448. ClITEUR, supra note 447, at 3 (quoting Daniel Philpott, The Challenge of September 11 to Secularism in International Relations, 55 WORLD POL. 66, 69 (2002)); Gorski \& Altınordu, supra note 444 , at 56 ("[M]ost would have agreed with the general thrust of the argument: that modernity was somehow undermining the social significance of religion.") (internal citation omitted); Evans, supra note 397 , at 1 ("It was not so long ago that confident predictions were being made about the eventual demise of religion. Religious people complained that liberal states had privitised religion; excluding it from the public square until such time as developments in science, education and philosophy rendered religion entirely obsolete.").

449. Cliteur, supra note 447 , at 1 .

450. See generally Hadden, supra note 444.

451. Buckser, supra note 416, at 207; Gorski \& Altınordu, supra note 444, at 56 (Influential events include " $[t]$ he rise of the Moral Majority, the Iranian Revolution, the collapse of communism qua secular religion, the rapid spread of Pentecostalism in the global South, communal violence in South Asia. These and other developments challenged the confident pronouncements of religious decline that humanists, rationalists, and social scientists had been repeating since the days of Hume, Voltaire, and Comte, to name only the best known.") (internal citations omitted).

452. Schultz, supra note 442, at 170. See also Mark Chaves, Intraorganizational Power and Internal Secularization in Protestant Denominations, 99 AM. J. SOC. 1, 2 (1993) ("[N]ew religious movements continue to arise; older movements like Pentecostalism and Mormonism are expanding; and, at least in the United States, huge segments of the population continue to say that they believe in God and continue to participate in orthodox organized religion."). 
theory proliferated. ${ }^{.453}$

"The central claim of the critique is that, if secularization is defined as the decline of religious beliefs and practices in modern societies, the theory of secularization is bunk." 454 "Not only has religion persisted (and the evidence is incontrovertible) but the theory also implies that the past was more religious than today, which, it turns out, is not so easy to prove." ${ }^{\prime 45}$

Some scholars have attempted "to salvage the idea behind the theory but to soften its predictive capacity, or to shift the definition of secularization by emphasizing different aspects of what secularization means." ${ }^{, 456}$ Mark Chaves, for example, has suggested that secularization most appropriately refers to a decline in religious authority, apart from individual belief.457 Charles Taylor sees a change in the conditions of belief; that is, secularization concerns a change in what it means to believe and to be a believer. ${ }^{458}$ Alexandra Walsham discards the term entirely in favor of "desacralization" when discussing the decline in belief in divine immanence. ${ }^{459}$

The process of secularization, therefore, has a multiplicity of understandings, including at a minimum the pre-modern transfer of property; the classical understanding of decline in religiosity, belief, or observance; the decline of religious authority, per Chaves; the change in the significance of religious observance, per Taylor; and the desacralization or disenchantment, per Walsham. These are certainly not the only ways secularization could be understood. ${ }^{460}$

453. Schultz, supra note 442 , at 174

454. Id.

455. Id.; Mark Chaves, Secularization as Declining Religious Authority, 72 SOC. ForCES 749 , 753 (1994) ("[I]t is no longer possible to truthfully assert that 'modernity' is incompatible with religious belief."); Chaves, supra note 452, at 2 ("“[C]lassical' secularization theory . . is no longer tenable."); Buckser, supra note 416, at 208 (Some of the problems of applying secularization theory to the Jewish experience stem from "the largely Christian orientation of secularization theory, which has generally followed the Protestant tradition of privileging belief over other modes of religious engagement.").

456. Schultz, supra note 442, at 175; Buckser, supra note 416, at 207 ("Critiques of secularization began to emerge, and in response a number of sociologists developed more precise and sophisticated models of the process."). For a thorough discussion of the current sociological approaches to secularization, see Gorski \& Altınordu, supra note 444, at 58-62.

457. Chaves, supra note 455 , at 754-56; Chaves, supra note 452 , at 7-8.

458. Charles TAYLoR, A SECUlar AGE 3 (2007).

459. Alexandra Walsham, The Reformation and 'The Disenchantment of the World' Reassessed, 51 HIST. J. 497, 504 (2008). Walsham contrasts "desacralization" as concerned "with the decline of belief in divine immanence" with "secularization," which she describes as "the rejection or marginalization of religion per se." Id.

460. See generally Olivier Tschannen, The Secularization Paradigm: A Systematization, $30 \mathrm{~J}$. SCl. STUD. RELIGION 395 (1991) (discussing theoretical diversity of approaches to studying secularization from the sociological perspective). 


\section{B. Disassociation as Secularization}

Here I suggest that one form of secularization may be seen where (originally) religious concepts are stripped of their religious character. The concept becomes disassociated with religion and assumes a cloak of neutrality, possibly even approaching objective detachment. A general example of this phenomenon can be seen in what N.J. Demerath III has called the "paradoxical decline of liberal Protestantism."

Demerath notes that "the decline of liberal Protestantism seems paradoxical. It can be construed as evidence both for and against the oncereigning model of long-term "secularization." 461 "Insofar as any churches are waning, this would seem ipso facto evidence of secularization." ${ }^{\$ 42}$ "However, because some liberal churches have suffered more than many conservative groups, it is conceivable that just the opposite trend is at work." ${ }^{463}$

Demerath suggests that " $[t]$ he decline of liberal Protestantism may actually stem from its success" $" 464$ and that "liberal Protestants have lost structurally at the micro level precisely because they have won culturally at the macro level." 465 In other words, the decline of liberal Protestantism "may be the painful structural consequence of Protestantism's wider cultural triumph." ${ }^{466} \mathrm{~A}$ church that promotes individualism, freedom, pluralism, and tolerance does so at its own organizational peril because holding these values may "reduce any organization's compelling claims by making its virtues relative." ${ }^{467}$ Similarly, promoting democracy "attenuates power" and promoting intellectual inquiry may be "corrosive for keeping the faith," particularly propositional faith. ${ }^{468}$ In its drive to emancipate the world, mainline liberal Protestantism may have "emancipated its own membership." ${ }^{\text {"469 }}$ Liberal Protestantism's cultural victory put itself out of business. In fact, De Roover sees this secularization-as-universalization as typical of Christianity more generally. ${ }^{470}$

The same sort of phenomenon may be at work in how religion has come

461. N.J. Demerath III, Cultural Victory and Organizational Defeat in the Paradoxical Decline of Liberal Protestantism, 34 J. SCl. STUDY RELIGION 458, 458 (1995).

462. Id.

463. Id. at 458-59.

464. Id at 459-60.

465. Id. at 463.

466. Id. at 460 .

467. Id. at 461 .

468. Id.

469. Id. at 462 .

470. See de Roover, supra note 440, at 51 ("Christian religion . . expands . . through a moment of secularization, whereby it achieves universalization in fact by progressively losing its specific form."). Cf. Stolzenberg, supra note 439, at 31 ("The concept of the secular has itself, ironically, been secularized."). 
to be seen as an a-religious category. As nonreligious bodies adopted Liberal Protestant values, the religious roots of concepts like "human rights" faded from memory. ${ }^{471}$ Here, the success of Christianity and the domination of European states universalized the understanding of religion as belief to such an extent that its religious origins have been largely forgotten. Secularization as "de-religifying," rather than merely desacralization, may be a useful line of further inquiry because, as I have suggested in this Article and elsewhere, ${ }^{472}$ misunderstanding and inequalities persist precisely because of ignorance of the religious roots of common concepts.

\section{CONCLUSION}

Margaret Davies has explained that

[a]t a subtle and therefore insidious level...., the situatedness of law within a cultural context and history means that certain principles based on religion rather than reason or practicality are embedded in law: these can be difficult to remove or challenge, even when there is very good reason to do so. ${ }^{473}$

Here, I have tried to show that one principle based on religion (here, Christianity) is the very notion of religion itself. I have also tried to lay out some of the reasons why even a non-Christian state such as Israel might encounter significant difficulties in defining religion, itself a Christian concept, on anything other than Christian terms, and suggest how such an understanding might come to be assumed by courts to be neutral, objective, and secular.

"The concept of religion has never been uncontentious." $"$ "774 In the trio of cases addressing who is a Jew, many Justices have explicitly assumed that Judaism (or, at least, the status of being a Jew) is a "religion" in the same sense that Christianity is a religion; that is, by defining membership largely, if not exclusively, on the content of beliefs, ${ }^{475}$ and assuming that religion and nationality are separable. ${ }^{476}$ Daphne Barak-Erez suggests that there was "an expectation that Israel's character as the state of the Jewish people would be reflected in its legal system and its public sphere."477

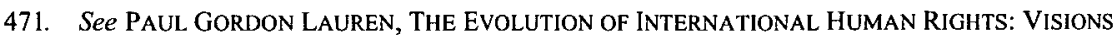
SEEN 4-20 (1998).

472. See generally Petty, supra note 6 .

473. Davies, supra note $\dagger$, at 79. See also Marc Galanter, Secularism East and West, in SECULARISM AND ITS CRITICS 234, 254 (Rhajeev Bhargava ed., 1998) ("[T]here may be "predominant religious aspects' in situations in which the actors are mainly unaware of them.").

474. Woodhead, supra note 389 , at 121 .

475. See Rufeisen, supra note 196, at 20-22 (opinion of Landau, J.); id. At 24, 31-32 (opinion of Berinson, J.); Beresford, supra note 340, at 56 (opinion of Barak, J.).

476. See supra notes $277,287-88,295,300$, and accompanying text (discussing Shalit).

477. BARAK-EREZ, supra note 2 , at 34 . 
With respect to how the state understands religion, the Supreme Court of Israel has left that expectation largely unfulfilled. 